\title{
THE GEOLOGY AND PETROLOGY OF THE GREAT SERPENTINE BELT OF NEW SOUTH WALES.
}

Part iii. Petrology.

By W. N. Benson, B.A., B.Sc.

(Plates xxv.-xxvii.)

Before commencing the detail of this chapter, I wish to record my indebtedness to many friends, for advice and assistance in this portion of the work. Professor Bonney has given me constant help, placing his unrivalled knowledge and collections of ultrabasic rocks at my disposal. Mr. Harker has rendered every assistance possible in checking petrological determinations, and directing me to the broader aspects of the work, and the most useful literature. Mr. Hutchinson has guided me through analytical difficulties, and has given every facility for working in the Mineralogical Laboratory at Cambridge. To the guidance of Dr. Flett in the Lizard area, and of Mr. Dewey in North Cornwall, I am indebted for field-knowledge of English serpentines and spilitic rocks; while, by permission of the Director of the British Geological Survey, and the Petrologist, Mr. H. H. Thomas, I have been able to examine the official collections of slices of these rocks Many useful facts, also, were gleaned from a study of the collections of the University of Paris, to which I was given access by Professor Lacroix. To all these gentlemen, I offer most hearty thanks.

The following chapter is based upon a collection of about 900 specimens, and over 320 microscopical slides of rocks gathered from all parts of the area. These are very varied in character, and must be described under many heads. The igneous rocks are treated in the first portion of this chapter; the breccias, agglomerates, tuffs, and normal sedimentary rocks in the second portion. 


\section{A. Igneous Rocks.}

These are described in the order of their geological age, as far as is known, and the following divisions are adopted:-

1. Devonian spilite-lavas.

2. Keratophyre of Hanging Rock.

3. Dolerite-intrusions associated with the spilites.

4. Lower Carboniferous lavas.

5. Middle Carboniferous peridotites, ete.

6. Gabbro-rocks associated with the peridotites.

7. Certain post-peridotite dolerites, and some acid dykes in the serpentine.

8. The Blue Knob group of dolerite and dolerite-porphyrites.

9. Granites, granodiorites, and porphyries, varying in age from late Carboniferous(?) to early Mesozoic.

10. Lamprophyres.

11. Alkaline rocks of the Nandewar Mountains.

12. Tertiary basalts, with the basanites, teschenites, and dolerites of the Nundle district.

(1)The Spilites. - The name spilite, according to Brongniart's original definition and Continental usage, indicated somewhat altered lavas of a gabbroid composition, characterised by an amygdaloidal structure, platy or spheroidal parting (pillow-structure), a tendency to a variolitic texture, and an abundance of secondary silicated minerals, the last feature being especially emphasised. Messrs. Dewey and Flett, however, have confined the term to those rocks which are characterised by the presence of a very sodic plagioclase, primary or secondary. Such rocks are very widespread, very uniform in mineral-features and chemical composition, and should certainly be classed under a specifie name; but it is very questionable whether the old term "spilite" should be revived and redefined for this purpose. Many of the rocks, formerly classed as spilites, do not fall into this narrowed division, as e.g., the only spilite-analysis quoted by Rosenbusch (Elemente der Gesteinslehre. Edition of 1910, p. 410). Moreover, the rocks described below, while their mineralogical and chemical composition is clearly that of the spilites of Messrs. Dewey and Flett, their 
freedom from secondary silicates, and frequently non-amygdaloidal character remove them entirely from the group of spilites as recognised by Brongniart. The major primary characters, and not the accidental secondary features, are surely those of specific value. The name spilite, therefore, is applied to them, but in the hope that a better one will eventually be adopted.*

The spilites are extremely abundant in the lower portion of the Devonian System. They form several important flows in the Woolomin and Tamworth Series, and occur interstratified in the Bald win agglomerate. The breccias of the Tamworth Series, and the above agglomerate, are largely made up of fragments of spilite, and in the latter it is often very pumiceous. In hand-specimen, they are more or less vesicular, but rarely amygdaloidal. Very frequently they are quite compact, and sometimes resemble a dark green hornfels. The grain-size is usually small, and even, but porphyritic examples are not infrequent. About two dozen specimens have been sliced. The texture varies considerably; usually it is pilotaxitic, and exceedingly finely crystallised; often it is more coarsely grained, with more or less variolitic character. Again, it may approach the granular structure of some basalts.

The least altered specimen [N.T., 415*] occurs on the French man's Spur, near Nundle. It is rather less finely grained than usual, and has a granulitic to sub-variolitic ground-mass, with an occasional idiomorphic crystal of augite (Plate xxv., fig.1). The felspar is primary acid oligoclase; the augite is but slightly decomposed, with production of chlorite and epidote. In chemical composition (see Table i., p.704), this rock is quite analogous to the Cornish spilites described by Messrs. Dewey and Flett.

* Messrs. Dewey and Fletts' use of the term Spilitic Suite is even less justifiable. Surely a group of rocks embracing picrites, dolerites, sodaporphyries, and keratophyres is not well described as the "altered basic lava suite." I understand that these authors have, in preparation, an extensive memoir on these rocks, and I trust they will take the opportunity of reconsidering their nomenclature before establishing more firmly such inappropriate terms.

†These numbers refer to specimens in the Mining Museum, Sydney Duplicates of nearly all the slides specially mentioned here, have been deposited in the Sedgwick Museum, Cambridge. 
The more altered rocks are far more common. In these, the augites are generally changed to chlorite, with the development of much carbonates; more rarely they pass into fibrous amphibole. The felspars are frequently too decomposed for determination, and have been changed to paragonitic mica sprinkled with epidote. If the specimen has come from the eastern side of the serpentine-line, it is usually crushed and sheared, and veins of quartz, paragonite, epidote, or rarely prehnite may have been introduced. In other rocks, there is a varying amount of glassy residuum, with crystallites of magnetite and felspar, and globulites probably of augite. In others, the glass appears to be devitrifying. Felspar and augite are the main constituents, the former usually very altered, clouded with secondary mica, but when fresh it is usually very acid. Magnetite varies exceedingly in quantity, from great abundance to complete absence. It contains most of the titanium in the rock, as the augite is rarely purplish. A single pseudomorph, doubtfully referred to olivine (bowlingite), is the only approach to an indication of that mineral.

Porphyritic spilites are less abundant. One [M.B., 50], which occurs on the upper Bingara track, six miles south of Bingara, is quite free from magnetite. It contains felspar-phenocrysts (oligoclase albite), $3 \mathrm{~mm}$., in diameter, in a very finely granular augite and felspar ground-mass. The spilite-flow in the agglomerates on Anderson's Creek [M.B., 17] contains large phenocrysts of andesine, but with a hypocrystalline base filled with microlites of felspar, augite, and magnetite. In one southern rock [N.T., 277] the phenocrystic constituent, augite, is completely changed to actinolite.

The hypocrystalline types are best exemplified by the lava [N.T., 31] which flowed over the coral-reef, now forming the limestone on Moonlight Hill, south of Nundle (See p. 575). This is an excellent instance of skeleton-crystallisation. Magnetite has formed in small plates, standing perpendicularly out from the felspar microlites and from the long, ropy masses of dusty material, augite-globulites and carbonates (?), while there is some glassy background. The few larger felspar-crystals, with their swallow- 
tailed extremities, are a very marked feature (Plate vxv., fig.2), In some of the spilite-fragments included in the Baldwin agglomerate, this becomes even better marked. Among these, there are strongly pumiceous types.

The spilites, that occur east of the serpentine-line, are very abundant, and are greatly altered by pressure. Sometimes they have received a schistose structure, with phacoidal cleavage, and, if not vesicular, are easily mistaken for altered sedimentary rocks. An excellent example of these is M.B., 56, from Woods' Reef. This, when seen microscopically, shows that it has been sheared in several directions. Some shear-lines are marked by finely pulverised rocks, the adjacent felspar-laths being sometimes dragged out and bent. Crossing these, are numerous carbonate-filled veins, which have been slightly sheared also.

N.T., 283, is a spilite from Folly Creek, near Nundle, occurring adjacent to the serpentines on Folly Creek, that have been changed to carbonates, and has been affected by the same solutions that altered the serpentine. The ferromagnesian minerals are gone, and much carbonate, tale, and a little pyrites have been introduced, while the rock has been much bleached.

(2)The keratophyre on Opossum Creek, Hanging Rock, forms a roughly circular area about 30 yards in diameter, and is probably a voleanic plug. It is buff-coloured, fine-grained, with calcitefilled vesicles [N.T., 195]. It is pilotaxitic in texture, composed almost entirely of laths of acid oligoclase. A few magnetite grains occur, but the augite, which occurred interstitially and in small phenocrysts, is completely replaced by chlorite.

(3)Devonian Dolerites.-These rocks have a medium grain-size, varying from 1-3 mm., in diameter. The texture of the rock is not constant; in one instance only is it gneissic; in the others, it is never more than subophitic, and, more usually, the augite is more prismatic and idiomorphic than the felspar, and is sometimes bent, through movement during consolidation. In these rocks, with both main constituents partially idiomorphic, there are interstitial areas filled in with finely crystallised, lath-like felspar or quartz-grains, or quartz and felspar conjointly. The constituent minerals are 
plagioclase, augite, titaniferous magnetite, apatite, and a little quartz and pyrites, but the proportions between the minerals vary greatly, as also does the type of felspar present. The handsome rock, forming the bold cliffs of Hanging Rock [N.T., 327] is one of the most felspathic (See analysis). It is composed of large, platy crystals of albite, very slightly decomposed. Between these, and eating into the main crystals, is a matrix composed of small, lath-like albite, sometimes with a roughly parallel structure, sometimes with an irregular, confused mat, like the felspar of some trachytes. The pyroxene is in irregular grains, sometimes imbedded in the large felspar crystals, frayed out at the ends, and rarely well bounded; often also it forms small wispy patches lying in the phenocryst or in the felspar mat (Plate xxv., fig. 3). The pyroxene is almost entirely converted into actinolite. Ilmenite and apatite, in small amount, make up the rest of the rock, together with a few grains of epidote. The spongy nature of the felspar, in this rock, seems good evidence of its secondary origin by recrystallisation through the action of sodic solutions. In others [e.g., M.B., 12; see analysis], the felspar is quite fresh in appearance, not at all spongy, and is albite. The pyroxene, however, is entirely changed to pale, fibrous amphibole. This rock is the "country" of a small quartz-reef, south-east of Bingara, and is associated with Tamworth rocks, though east of the serpentine-line.

The majority of the rocks, however, have a plagioclase of about the composition of andesine. Some slides [e.g., N.T., 197; also from Hanging Rock], show well how albitisation is proceeding inwards, with clarification of the dusty andesine. Its change of composition is clearly not zonal, as it occurs chiefly on the exposed parts of the crystals, i.e., where they project into the interstices. Concurrently; the amphibolisation of the pyroxene is in process. This rock is noteworthy for the abundance of the interstitial quartz, which is clearly primary. In other rocks, [e.g., N.T., 172, from near the Swamp Creek Falls (Nundle)], the pyroxene and felspar (ande sine) are both comparatively fresh. This rock intrudes into a fine. grained tuff, and contains small interstitial areas of pilotaxitie rock like spilite. 
The very coarse-grained dolerite-pegmatite, that occurs in the dolerite of Bowling Alley Point ('Possum Mine), is also not albitised; the felspar is andesine and the pyroxene is only slightly uralitised. It is intersected by many small veins of quartz and epidote.

In the neighbourhood of Horsearm Creek, Attunga, there is a series of dolerites altered by the granite-intrusion, and closely resembling the contact-altered albite-dolerites of Cornwall(35). A typical example [M.B., 177] has a structure approaching the ophitic type. Plagioclase is the dominant mineral, in large grains and smaller laths. The strongly pleochroic, green hornblende is probably derived from ophitic augite. Some crystals of the same mineral are scattered about interstitially. Numerous aggregates occur, composed of small crystals of biotite, together with some magnetite. A little interstitial quartz occurs with magnetite and abundant apatite-needles.

(4)Lower Carboniferous Lavas.-It has been shown that the Rocky Creek conglomerates are interbedded with flows of rhyolite and other lavas, and contain numerous beds of acid tuff. The pebbles of the conglomerate largely consist of material derived from the interstratified flows, together with much quartz, porphyry; granite, et cetera. While, as yet, the actual lava-flows have not been studied in detail, and the collections made are entirely from the pebbles of the conglomerate, it will be best to describe the lavas among them in this place, rather than as inclusions in the sedimentary series, to show better the sequence of igneous activity in the area studied.

A dozen rocks were sliced, which have all proved to be rhyolites of very varying character. The ferromagnesian minerals are very subordinate, and are usually biotite, often containing zircon. Magnetite is present in small quantity only.

The structures present differ considerably. In some [M.B., 9], the rock is holocrystalline, with phenocrysts of quartz and oligoclase, full of glassy inclusions set in a matrix of small felspargrains, in a granophyric ground-mass. In another [M.B., 10], the flow-structure is well pronounced, the flow-lines being marked by 
long rows of axiolites, with a central string of minute magnetite grains. Here and there, the flow-lines diverge around some phenocryst of orthoclase, or spherulitic patch, or quartz-area free from flow-structure (Plate xxv., fig.5). The glassy rocks have similar quartz and felspar phenocrysts, set in a ground-mass which may be purely glassy, with a definite flow-band on a rippling structure, or may be more or less homogeneous. This is usually devitrified, to a greater or less extent. In one interesting rock [M.B., 7], the phenocrysts, quartz, oligoclase, biotite, hornblende, and magnetite, are greater in amount than the glassy matrix in which they are imbedded.

In the last rock, the felspar is nearly all plagioclase, but, in the majority of the rocks, orthoclase is abundant. This point is important, as it would show this series of rocks to be normally potassic lavas, not sodic keratophyres; and, therefore, not part of the spilite-keratophyre group, as instituted by Messrs. Dewey and Flett. The lavas, here described, have not been chemically investigated, but they are almost certainly comagmatic with the Carboniferous rhyolites of the Maitland District, described by Walkom and Browne(13), which are normally potassic, as may be seen from Mr. Mingaye's analysis. Walkom and Browne's analysis of a pitchstone, from the same region, would, however, show that sodic rocks are also present.

A rock [M.B.,233] occurs in Jerry's Creek, four miles south of Crow Mountain, which may possibly be connected with this series. It consists of xenocrysts of plagioclase and augite, which have been rolled about in a cooling lava. The rock has a regularly slaggy structure, and bent microlites of felspar throng its brown, glassy ground-mass (Plate xxv., fig.6).

(5). Peridotites and associated Rocks. - The ultrabasic rocks are fairly constant throughout the whole length of the serpentinebelt. As shown by Mr. Anderson(1), the dominant rock was a harzbergite, but locally, by diminution in the amount of enstatite, the rock approaches to the dunites, while the presence of diallage throws the rock into the lherzolites. Diminution or absence of olivine gives an enstatite-rock, "Enstatolite" of Pratt and Lewis(35). 
Chromite is not common in the pyroxenites, but, in the peridotites, it may increase in amount, until it becomes the dominant constituent.

Associated with the peridotites and pyroxenites, are rarely amphibolites and olivine-gabbros, more frequently eucrites and anorthosites. No picrites, troctolites, and norites have been found yet.

The rocks will be described under the following divisions :(a) Peridotites; (b) Pyroxenites; (c) Amphibolites.

(a). The peridotites are almost entirely harzbergites. It is rare that diallage is present in sufficient amount to cause the rocks to pass into the lherzolites, while the proportion of rhombic pyroxene is almost always too great to allow the rock to be classed as a dunite. There are three main structures developed, the granular, porphyritic, and poikilitic. In the first, the grains of olivine and enstatite are roughly equal in size, being about $2 \mathrm{~mm}$. in diameter, while the small chromite-grains rarely exceed $\frac{1}{2} \mathrm{~mm}$. in diameter. This last mineral has two forms of occurrence. In most cases, it forms irregularly shaped, but not angular grains. In other cases, it is quite granophyric in habit, running in irregular, twisting and branching strings; and while not forming a definite granophyric intergrowth with its host, it seems generally associated with monoclinic pyroxene. Sometimes the strings of chromite rise perpendicular from the outer boundary of the enclosing crystal [bastite in N.T., 238].

In the porphyritic rocks, the pyroxenes are distinctly larger in size than the olivine. As is seen elsewhere, in thoroughly serpentinised rocks, there may be developed a false porphyritic appearance, owing to the enstatite changing intact to large plates of bastite, while the olivine has formed a small meshwork of serpentine. In the poikilitic or lustre-mottled types, large bronzite crystals form the ground-mass of the rock, in which smaller olivine-grains are set. The best examples of this type of rock may be obtained on Chrome Hill, behind Bowling Alley Point, where plates of bastite four inches long, studded with serpentinised olivine, have been collected. They are a deep brown in colour. 
So far no examples of bending, as an original structure, ("Schlieren") have been obtained.

No rocks yet found in the belt have escaped chemical alteration. The processes of alteration may be classed as :-( $\alpha)$ Normal serpentinisation; $(\beta)$ Change to antigorite; $(\gamma)$ Carbonation; $(\delta)$ Silicification with oxidation.

The two latter occur together, the one or the other predominating, and both are subsequent to the two former. The products of these processes further differ according to the degree of pressure they have undergone during their change.

(a). The formation of normal serpentine has been so often described, that a brief note will here suffice. The process affects, but in different ways, olivine, enstatite, and diallage. Olivine produces its well-known mesh-structures, with, frequently, separation of magnetite, which is generally deposited in the strings of the mesh, along the first-formed cracks; occasionally these cracks are quite free from magnetite, and the deposition is in the interstices of the mesh [e.g., N.T., 132]. Enstatite forms large, clear, platy pseudomorphs, with occasional deposition of magnetite in the cleavage-cracks. Usually the enstatite becomes very cloudy while the change is in process, but the finished product, bastite-serpentine, is quite clear. The alteration of the diallage is not exhibited by any of the New South Wales serpentines, further than the grain becoming cloudy, and a small amount of serpentine forming in the narrow cracks. The chromite is quite unaltered during this change, and in all subsequent changes also.

There are two types of massive serpentine, which are more clearly distinguished in the field than under the microscope. One marks a strong outcrop, with a rough weathering surface stained red or brown. The olivine-serpentine is etched out on weathering, the bastite and talc remain in high relief. On fracture, the rock is dark, often poikilitic, and frequently contains small, irregular, white patches of steatite, which is exceedingly finely divided and nearly isotropic, owing to mutual compensation. The chemical and physical difference between this type of rock and its derived soils is shown by the difference in soil-colour, here reddish, and in the vegetation. 
The other massive serpentine is more purely magnesian, weathers to a fairly smooth surface, and whitens by change to tale, which mineral also forms small veins rarely. Frequently, the rocks show green and cream-coloured patterns, in varying shades, of great beauty, reminding one of "alligator-skin" leather. Rarely they are reddish, and, in one instance, the rock is vesicular [N.T., 218]. Some constituent has been removed, leaving very irregular cavities, but what that mineral was, is not at all obvious. On fracture, the rock shows a fairly smooth, sometimes oily, green surface flecked by bastite-crystals.

The least altered rock [N.T., 388] occurs in the lower portion of Munro's Creek. It is chiefly yellowish serpentine, with very numerous olivine-residuals in its meshes. The pyroxene is diallage, which has a poikilitic structure. It is but slightly altered, the serpentine growing out from its cleavages, or inwards from its outer margin. The presence of the monoclinic pyroxene makes this rock one of the few lherzolites yet observed in the area. Chromite is present in only small amount, but white, cloudy masses of steatite are not infrequent.

The effect of pressure is first marked by the production of an undulose extinction in the bastite, and the development of chrysolite-veins throughout the rock. In these, further movement shears the fibres, breaking them into frayed wisps; small veins are formed, traversing the olivine and bastite serpentine, filled by fibres and plates crossing them perpendicularly, and these later become sheared out of position. The movements naturally tend to take place along the major mesh-lines of the original serpentinisation, which are marked by the presence of long strings of magnetite. In such rocks, the original enstatite may be represented by only an oval patch, with a slightly less sheared structure, and a greater freedom from bastite than the rest of the rock. Ultimately even this distinction is lost.

A few examples may be specially noted. The serpentine, in the highly displaced rocks of Gulf Creek Mine, shows shearing developed to its greatest degree. The lenticle is apparently fairly narrow. Its best exposure is in the Mine-workings, for it is scarcely seen on the surface; and it seems quite impossible, 
that the hydration of that small band of serpentine could be the cause of its own shearing and the local dislocation. In the main intrusion, the schistose serpentines tend to occur along the east wall, and, to a less extent, on the west wall of the intrusion, points where the easterly thrust would be most felt. Here, the massive serpentine is locally drawn out into schistose serpentine, leaving "eyes" of massive rock imbedded in the schist, gradually diminishing in size till the zone of maximum shear is reached. This is a feature sometimes observed in Alpine serpentines (fide Professor Bonney).

A few rocks occur, in which pressure has produced a linearparallel, rather than a lamellar-parallel or schistose structure. This seems to be the result of simple pressure without shear. Such rocks are rare, but instances occur at the Lone Hand Mine, south of Bingara [M.B., 199] and elsewhere, less well developed.

From Mr. D. A. Porter, I have received a serpentine occurring probably near the head of Attunga Creek. It is a bastiteserpentine traversed by numerous parallel veins of chrysotile, about half an inch apart, narrow where traversing the bastiteerystals, but splitting up into finer, anastomosing veins where crossing the intervening olivine-serpentine (Plate xxvi., fig.7).

$(\beta)$. Before describing typical antigorite-serpentines, a group of rocks should be mentioned, that appear to show the first stages in the transformation into antigorite-serpentine. For convenience, these may be termed "felted serpentines." The mass of the rock is a fine, grey-brown, felt-like mass of a dusty nature, polarising in yellowish tints. In the main, its appearance suggests derivation from a pyroxene, perhaps diallage, for true bastite occurs also, and a kind of mesh-structure in some portions likewise. Small, branching veins traverse the rock, bordered perpendicularly by chrysolite-fibres; and sheared chrysolite-veins may be present also[e.g., N.T., 143; a compact, mottled-green serpentine from the mouth of Sheep Station Creek, Bowling Alley Point]. The further stage in alteration is exemplified by N.T., 103, occurring on the Peel River, a mile to the north-west. In this, the dusty-brown material has diminished in quantity; wide zones, separating the dusty areas, consist of mica like 
antigorite-flakes growing out perpendicularly from a central crack, and stabbing into (clearly replacing) the dusty portions. Some pseudomorphs of bastite present, are also being replaced in the same manner, but the process has not gone on so far. Granophyric chromite is also present.

An interesting series of slides shows the successive steps in the replacement of normal mesh-structure serpentine by antigorite. An early stage is shown in N.T., 258, from Munro's Creek. This rock is a harzbergite, so poor in pyroxene as to pass almost into the dunites. It has first been serpentinised in the normal manner, and the typical mesh-structure is well seen, accompanied by the usual disposition of the lines of magnetite-particles. The pyroxene has passed into bastite. The rock is traversed by major cracks, marked by a plentiful amount of magnetite-dust, on either side of which, the normal serpentine has been recrystallised as antigorite, forming large flakes parallel, transverse, or

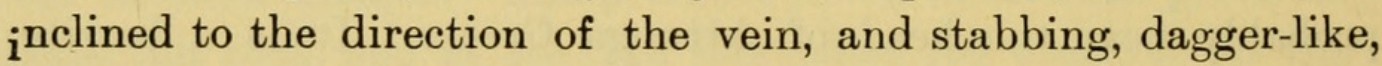
into the brownish mesh-serpentine on either side. Here, again, the replacement of the bastite is not so far advanced (Plate xxvi., fig.8).

More advanced in this alteration, is N.T., 383 (Plate xxvi., fig.9), a massive serpentine from the Razorback, in Munro's Creek. The rock was a bastite-serpentine. The whole of the ground-mass has now become antigorite, disposed in small plates aggregated into sheaf-like bundles, spreading and fraying out at either end. Often two sheaves cross one another at right angles, their separate elements appearing as if interwoven, while the outer portions may spread so widely as to give the whole mass the appearance of a spherulite. The large bastite-plates are still present, but in them, also, the change to antigorite is in process. The mineral is arranged in similar though large sheaf-like masses, single or crossed, the warp and woof of the matted plates being very distinct. Single flakes of antigorite also occur, with their characteristic, sharp, dagger-like outline in the bastite groundmass The position of the strings of magnetite-particles alone remains to show the original mesh-structure of the matrix of the rock, A little chromite and carbonates are present. The 
chemical composition of this rock is of the normal serpentinecharacter (See analysis, Table ii.).

Finally, the completely changed rock is seen in N.T., 491, from the same locality. All the bastite has passed into antigorite, its former position being indicated by areas in which the magnetitedust occurs in parallel bands. In the remainder of the rock, the magnetite is in the irregular bands and kernel-aggregates, characteristic of ordinary olivine-serpentine mesh-structure. The position of the pseudospherulites of antigorite is quite without relation to the magnetite-bands, and, consequently, without any reference to the original cleavage of the pyroxene-minerals, of which they are the second derivative. Moreover, the appearance of the interwoven sheaves, both in the olivine and pyroxenic areas, as combined with the straight extinction of the antigorite, which makes just those portions that are at right angles, in the $45^{\circ}$ position, in polarised light, gives so close a similarity to what has been termed "gitter struktur" as to strongly support Professor Bonney's contention, that this structure is more apparent than real, and by no means a valid indication of the presence of pyroxene(36). This rock also contains a small amount of carbonate.

Antigorite-serpentines also occur in the northern region, but differ in structure from those described above. A good example of these is M.B., 319, which occurs in Hall's Creek, fourteen miles south of Bingara. This is a dark green rock, with a granular fracture. It consists of blade-like, platy antigorite, usually arranged standing perpendicularly to a parallel series of cracks. Often the arrangement is much more irregular. Scattered about the rocks are irregular grains of chromite. The rock passes, in the spaces of an inch, into a mass of fibrous, radiating, pale green tremolite. The small width of passage-rock is very beautiful in microscopic section, the antigorite being interspersed with long prisms, diamond-shaped cross-sections, or isolated, radiating aggregates of tremolite-prisms (Plate xxvi., fig.10). The tremolite is frequently surrounded by that most perplexing, greenish decomposition-product, which Lacroix, while retaining the original name bowlingite, considers to be probably a variety of idding- 
site(37). It has a very fine, confusedly fibrous structure, high birefringence, often low by mutual compensation, and varying green to brown pleochroism. A careful description of this mineral was given by me, in a paper on some basic inclusions in the Dundas volcanic pipe near Sydney(38). The suggestion there was, that the mineral was produced by the action of atmospheric agencies, as is usually the case.

As pointed out by Professor Bonney (op. cit.), it is nearly always possible to distinguish an antigorite-serpentine in the field. It is peculiarly tough under the hammer, and breaks with a rather rough, granular fracture.

As antigorite-serpentine is frequently present in the Alpine areas that have suffered the greatest pressure, a series of densitydeterminations was made, to discover whether there was any change in the passage from normal to antigoritic serpentine. Five rocks were chosen, which, from their colour and microscopical appearance, were considered to be the most nearly allied in composition, and two carefully selected chips of each were used. The results were as follows :-

N.T.,215. Mesh-serpentine and bastite rather deficient in magnetite ... ... 2.570 to 2.598

N.T.,230. Mesh-serpentine and bastite $\quad \ldots \quad 2.602$ to 2.611 N.T.,240. Mesh-serpentine and bastite _.. $2 \cdot 612$ to $2 \cdot 615$

N.T.,383. Antigorite-serpentine with bastite 2.597 to 2.617

N.T.,491. Antigorite-serpentine ... .. $2 \cdot 620$ to $2 \cdot 632$

The difference in specific gravity, between an antigorite- and a normal serpentine, is thus within the limit of variability of a single specimen. Though the antigorite appears slightly the higher, this may be due to the presence of magnetite, the specific gravity of which is $3 \cdot 1$. It may be concluded that the formation of antigorite from mesh-serpentine is not accompanied by any notew orthy change in density. The first serpentinisation is, of course, associated with a decrease in density. The least altered peridotite present, N.T., 212, has a mean specific gravity of $2 \cdot 815$, while a rather more serpentinised rock has a mean density of $2 \cdot 739$. Fresh harzbergite varies, as a rule, from $3 \cdot 17$ to 3.35 in specific gravity (Rosenbusch). 
$(\gamma)$. The carbonation of the serpentine naturally resulted in the freeing of a considerable amount of silica, so that the rocks of this group may be considered as overlapping, to some extent, those of the next group, $(\delta)$ the silicated rocks. They are developed to a great extent between the Folly and Quackanacka Creeks, near Nundle, and occur at intervals along the western side of the intrusion, from Crow Mountain northwards, forming very large masses near the head of Hall's Creek, "Red Rock," and on Myall Creek, near Bingara. The Folly Creek rocks are pseudomorphous after massive bastite-serpentine. They consist of talc and carbonate in varying proportions, with dusty magnetite, which is so disposed as to show conclusively that it was developed during serpentinisation, prior to the carbonation, for it lies in the mesh-structure of olivine-serpentine, on the parallel lines of bastite-serpentine.

In N.T., 280, and, to a less degree, N.T., 176, 294, and 297, the bastite pseudomorphs can be seen, in hand-specimen, as large, purplish-grey plates, splitting along the original bastite-cleavage. Microscopically, they are composed partly of fine, matted talc, with a general arrangement parallel to the lines of magnetite, and partly of roughly idiomorphic carbonate-crystals without regular orientation, though, in some, the magnetite-lines are the major diagonals of their cleavage-rhombs, i.e., the original bastite cleavage-planes become the basal planes of the carbonate-crystals. Occasionally [e.g., N.T., 176], there is developed a little micaceous mineral parallel to the same bastite-cleavage, with a marked green to yellow pleochroism. It is probably clinochlore. The olivine-serpentine ground-mass is also composed of talc and carbonates, the latter being more irregular in shape, and appearing occasionally to replace residual olivine. The arrangement of talc is sometimes radial, generally matted. The chromite-grains, in the specimens examined, are usually granophyric, and analysis shows that one [N.T., 280] contains 0.55 per cent. of chromic oxide (See Table ii., p.705).

The schistose carbonate-rocks show also, though not so definitely, their derivation from serpentine by chemical changes. The rock near the Trevena Mine, on Folly Creek, is strongly 
sheared, and is composed of light and dark carbonate-grains, with numerous cross-veinlets. The talc and carbonates are very irregularly distributed, and the former presence of chrysoliteveins is occasionally indicated. The distribution of the magnetite is typically that of a sheared serpentine-rock. Sometimes the rock is silicified by the development of chalcedonic veins.

The rocks on Eumur Creek, Crow Mountain, 20 miles southeast of Barraba, are also interesting. They are both massive and schistose. The surface is brown, and the silica-veins are etched out by chemical erosion. On fracture, they are flesh-pink, with carbonate and clear siliceous veins. Small, green patches occur, which prove to be chalcedonic replacements of serpentine, stained with a little green chlorite. They are sometimes very finely granular, but occasionally are quite coarsely grained; the carbonate-mineral (ankerite?) is quite idiomorphic, and grows out on either side of the shear-lines that anastomose throughout the rock.

The ore-body of the Trevena' Mine mentioned above, should also be described here. It is a creamy-white rock, sometimes quite friable, with a glistening appearance suggesting a decomposed, fine-grained greisen (and it is locally termed greisen). It is full of large and small cubical pyrites. Microscopically, it varies somewhat in character. One specimen consists of radiate spherulites of talc, $1 \mathrm{~mm}$. in diameter, dotted with small apatitecrystals and well-developed, sagenitic webs of rutile. The pyritescrystals are in strings, with perfectly formed, minute rhombs of siderite deeply stained by the separation of hæmatite. In other examples, e.g., N.T., 504, the talc is in little flakes, placed in such a manner as to suggest derivation from antigorite. There is a little brownish, almost isotropic, matrix, chiefly chalcedony; and into this, the talc-plates cut sharply, rather in the dagger-like manner of antigorite. A little quartz is present, with pyrites and sagenite. Some rocks are very siliceous [e.g., N.T., 499], consisting of quartz with very undulose extinction, talc with pyrites, carbonate, etc. The footwall of the ore-body [N.T., 492], is a green and grey mottled rock, consisting of finely divided talc, with an antigorite (pseudo-gitter) arrangement. It is dotted 
with grains of carbonate, and the disposition of the abundant magnetite-dust suggests the former presence of bastite.

$(\delta)$. The silicated rocks are also widespread. They are best developed at the head of Oakenville Creek, near Nundle, at the head of Munro's Creek, and the mouth of Sheep Station Creek valley, near Bowling Alley Point. While silicification may occur with carbonation, it is often quite a separate process. In the Sheep Station Creek rocks, normal, partly sheared bastite-serpentine passes into isotropic opal, and becomes veined, small openings are dissolved out, and these become lined with radiating chalcedony [N.T., 130]. In the further altered rocks, such as those of Oakenville Creek, the greater part of the serpentine may be dissolved away. The magnesia is removed, and the iron remains as limonite-powder, in the meshes of a network of large and small silica-veins, with vughs lined with chalcedony and quartz-crystals. In fact, a regular sinter is produced. In some of these "vughs" the magnesite is deposited in dense white, roughly mammillated masses. Particularly fine specimens of chalcedony, in mammillated or stalactic form, used to be obtained on Dangar's Gully, a tributary of Oakenville Creek.

In Spring Creek, about two miles south of Moonbi Railway Station, is an opaline sinter, passing into massive, white opal, stippled with small dendrites [N.T., 471].

Non-sintery, secondary silica-rocks are also divisible into massive and schistose groups. Among the massive types are some pyritous chalcedony-rocks, products of extreme silicification, associated with the carbonate rocks of Folly Creek[N.T., 181,182]. These appear to contain finely divided talc. The rocks between this point and Munro's Creek consist of bottle-green opal with white veins, and a considerable amount of talc. The hæmatite thrown out forms a deep red, silicified covering around the green interior in some cases [N.T., 150], while in others, there are small cavities lined with chalcedony [N.T., 122]. In the same locality is a slightly schistose, pale green rock with dark green kernels [N.T., 153]. This consists of pale brown opal crowded with tiny plates of talc, and containing a few small crystals of chromite. A somewhat similar green-veined talc-bearing rock is the sole 
representative of the serpentine on Cope's Creek, five miles north of Bowling Alley Point. On Chrome Hill, the eastern side of the serpentine is highly schistose, streaked with grey and green in an opaque white, talc-bearing, siliceous ground-mass, which has thin films of limonite in all its shearing surfaces [N.T., 44].

We see, therefore, that, here, change to normal serpentine may be followed by a further change to antigorite, or by carbonation and silicification, with introduction of metalliferous minerals. The significance of these observations will be fully discussed in a later communication.

(b). The pyroxenites are those rocks in which pyroxene becomes dominant over the olivine. They are not at all abundant. In two localities only have they been found to any extent. At the head of Hall's Creek, south of Bingara, they are most abundant. They consist [M.B., 323] of olivine passing into serpentine with the mesh-structure and talc; enstatite, changing along the cleavages and on the periphery to green and brown anthophyllite, and white, colourless tremolite passing from the boundaries out, parallel to the vertical axis of the crystals; and diallage interlaminated with the enstatite, and in separate grains which are less altered. A little granophyric chromite is present also.

The rock from the head of Yellow Rock Creek, south of Crow Mountain [M.B., 197] is almost a pure enstatite-rock. It contains very little diallage and olivine, and is decomposing directly into talc, with here and there a little serpentine.

$(c)$. The amphibolites are even more rare. They occur at the Paling Yard, north-east of Barraba, and form the country of the peculiar orbicular chromite. The unaltered rock [M.B., 189] is compact, green, rough to the touch, and exceedingly tough under the hammer. It is composed entirely of nearly colourless, tremolitic hornblende, which is prismatic in habit, rarely reaching a greater length than $1 \mathrm{~mm}$., and often multiply twinned. Scattered about interstitially is a very small amount of clinochlore with a noticeable pleochroism, yellow-brown to pale green. The double refraction is too strong to allow it to be pennine, which it resembles in pleochroism. The chemical analysis of this rock is fully confirmatory of the microscopical determination. The 
excess of potash over soda was unexpected, but a duplicate analysis gave almost identical figures.

The rock passes into a serpentine like antigorite; it does not appear so crystalline to the naked eye, but cleavage-surfaces remain, showing a bronzy lustre [M.B., 186]. These are due to the development of small schiller-plates in the amphibolecleavages. The serpentine, like antigorite, grows inwards from the periphery of the grains, and forms small, dagger-like flakes stabbing the residual kernels (Plate xxvi., fig.11).

Two curious rock-types, associated with the serpentine, may be mentioned here. The chrome-bearing rock at Paling Yard, east of Barraba, is quite unique as far as has been seen. It is pale green in colour, crowded with spheroidal aggregates of chromite about $5 \mathrm{~mm}$. in diameter (or less). They may vary in amount, from about $25 \%$ of the rock till, in extreme cases, they are present almost to exclusion of the serpentine-matrix. These spherules are made up of exceedingly minute, but perfectly crystallised chromite-cubes, and sometimes contain a little antigorite. The matrix is made up of bladed antigorite and kämmererite, the pink chrome-bearing chlorite. The latter is in plates, with a low birefringence and straight extinction. Occasionally, it shows a radial structure. The chemical composition of this rock [N.T., 475] is given in Table ii., p.705.

The other rock-type is very different. It occurs in fragments, in a water-race near the head of Oakenville Creek, Nundle; and, though not found in situ, it probably forms veins in the serpentine. The previous notice of this rock was by Mr. W. A. Dixon(39), who referred to it as a kind of chlorite. He described it as forming a vein in the serpentine, and stated it to be "massive translucent, with a sea-green colour, waxy lustre, and unctuous feel; gives a white streak and powder. In a sealed tube gives off water and becomes white; before the blowpipe it is infusible, but becomes opaque and reddish-white, and is not acted on by hydrochloric acid. Hardness 2. Specific gravity $2 \cdot 68$."

All the above statements hold for the specimens collected by the writer. The physical properties are those of pseudophite. Dixon's analysis (see Table ii.) does not give any recognisable 
formula, but a new analysis [N.T., 321] gives figures approximating to the chlorite-formula :

$$
5(\mathrm{Mg} \mathrm{Fe}) \mathrm{O},(\mathrm{Al} \mathrm{Fe} \mathrm{Cr})_{2} \mathrm{O}_{3}, 3 \mathrm{SiO}_{2}, 4 \mathrm{H}_{2} \mathrm{O} \text {. }
$$

The earlier analysis shows a great excess of alumina and deficiency of magnesia, and this is doubtless due to the use of only one or two precipitations of alumina with it. In the newer analysis, the first alumina-precipitate was noticeably more bulky than the second and third, and five reprecipitations, in all, were employed. Mr. Mingaye, on my calling attention to the unsatisfactory nature of the older analysis, made another, of a specimen in the Mining Museum in Sydney, with the result tabulated. This shows more alkalies and nickel, and less water than N.T., 321. The latter analysis was, therefore, checked and confirmed in the figures for those oxides. A real variation does, therefore, exist.

Other occurrences of pseudophite are quite different from this. Dr. Flett, in the Lizard(40), and Professor Lacroix, in the Pyrenees(28), have both noted pseudophite occurring with peridotite; but, in both cases, it replaced alkaline felspar, and showed a pseudomorphous character, and want of homogeneity. ${ }^{*}$ The Hanging Rock specimen is absolutely homogeneous and structureless, and so finely divided it is with difficulty possible to make out the individual chlorite flakes in the mutually compensating mass.

(6). The gabbroid rocks occur here and there, and in greater or less amount, all along the serpentine-belt. In the localities where they are but slightly developed, it is clear that they intrude into the serpentine; but where they are most abundant, as east of Cobbadah, their relationships are not so obvious. The original rocks must have been fairly uniform in character They were eucrites composed of pale green diallage and bytownite, and had an even, granitic texture, and medium grain-size. The exceptions to this were comparatively few, and comprise pegmatitic eucrites and olivine-gabbro.

* Mr. Howard Fox, who first noted this mineral at Kynance (Mineralogical Magazine, 1891, p.275) thought it replaced plagioclase. That is not possible at Gew Graze, but may be elsewhere in the Lizard. 
Many alterations have taken place. The most frequent change is the passage of the felspar into saussurite, so often described from other areas; but, in addition, grossularite and prehnitebearing rocks are developed, as well as other types.

Very few fresh specimens of eucrite are obtainable The least altered [N.T , 118] occurred south of Chrome Hill, Bowling Alley Point. Its pyroxene (chrome-diopside) is pale green in colour, almost mica-like, and is set in a matrix of clear, even-yrained plagioclase. The pyroxene, which is moulded on the felspar, has commenced to change into tremolite, and the specific gravity of the felspar $(2 \cdot 751)$ indicates that it is anorthite. This determination is confirmed by the analysis given [Table ii.].

The only olivine-gabbro found, occurs intruding into the serpentine in Spring Creek, Moonbi. It is a dark grey in colour, and very decomposed superficially. It consists of saussuritised plagioclase, with a little prehnite forming along the cracks; diallage irregularly bounded and intergrown with the plagioclase; and olivine in fairly idiomorphic grains, more or less decomposed into serpentine, and bordered by a band of noticeably pleochroic pink to white hypersthene, which is quite fresh.

The pegmatitic types are best developed on Chrome Hill, Bowling Alley Point. They consist of grey-brown pyroxene and white felspar. Sometimes the crystals are comparatively small, i.e., 3-5 mm., in diameter, but usually they are much larger; diallage-plates more than $5 \mathrm{~cm}$., in length, have been collected. These rocks frequently show ophitic structure very well developed in hand-specimens. A little magnetite may also be visible. Under the microscope, the diallage of most coarse-grained specimens was found to be more or less altered to tremolite, lying parallel to the vertical axis, or occasionally in a small knot of fibres. Dotted about the plate, and occurring especially around the periphery, are small, brown flakes and bands of hæmatite(?). The felspar is completely saussuritised, and there are a few irregular veins of prehnite. The smaller-grained examples [N.T., 7] are more interesting. The felspar is less altered. The diallage shows some peculiar intergrowths of several individuals of pyroxene. Along lines of cleavage, fracture, or other plane of weak- 
ness, the mineral has commenced to pass into tremolite. Usually this is placed parallel to the vertical axis of the diallage, and developed fairly evenly throughout the grain, giving it a peculiar, mottled appearance. In other cases, the whole plate will have passed into tremolite, forming a multiply twinned mass of parallel amphibole-fibres.

The normal types of highly altered, fine-grained eucrites in hand-specimen are opaque white, with dull green spots, just like the typical euphotides or saussuritic gabbros of the Alps and Appenines; and, under the microscope, show the same features. They consist of dusty diallage more or less completely changed to tremolite, and dull grey-white saussurite traversed by small veins of clinozoisite. The original twin-lamellæ of the plagioclase can still be seen in some cases, e.g., M.B., 327, from Upper Bingara. Occasionally, the saussurite would be flaked with lighter spaces, which consist of optically continuous prehnite. Rarely, hypersthene is found in these rocks, a good instance occurring at the old Paling Yard Diggings [N.T., 481]. The mineral is in rounded grains, about $3 \mathrm{~mm}$., in diameter, and is faintly pleochroic. In this rock, the felspar has altered in an unusual manner The cracks in some grains have been marked by the development of grey-brown, dusty bands, increasing in number until the whole mass becomes opaque. These pass into areas without sharp demarcation, which consist of very finely divided prehnite(?), while some of the diallage has passed into serpentine, partly fibrous, and partly platy; the hypersthene is quite unaltered.

In N.T., 469, from Moonbi, the felspar has changed entirely to rather coarsely granular zoisite, with characteristic blue interference tint. The diallage is much strained, but is otherwise unaltered.

Another modification occurs at Upper Bingara, and is distinguished by the presence of much prehnite. This striking mineral forms in veins; the individual grains are rarely as much as $1 \mathrm{~mm}$., in diameter. Its large, optical, axial angle, optically positive character, straight extinction, and high refractive index and birefringence are very characteristic. The saussurite, on either side, is seen to have passed almost entirely into a fine 
mosaic of prehnite-grains. It is evident that this change has taken place after the felspar has been partly saussuritised, with the development of dust-filled cracks; these now remain in the prehnite. The diallage in this rock [M.B., 17] is being altered, partly to tremolite, but chiefly to antigorite and pale pink garnet, occurring as little irregular blebs, formed owing to reaction with the felspar.

In another example of the development of garnet, the case is rather different. This rock [N.T., 417] occurred at Bowling Alley Point, and, in some features, recalled the rocks of the Paringû massif in Roumania, studied by G. M. Murgoci(41). The original minerals were apparently diallage and plagioclase only. The diallage is sometimes fresh, but usually only an outer shell remains, the central portion having passed into antigorite, which is bordered by numerous, small, colourless crystals of fassaite. The plagioclase, where in contact with the ferromagnesian minerals, has passed into a dusty aggregate of finely granular garnet, and small strings of these grains are working into the main mass of the felspar along the cleavage-cracks. * The development of prehnite, from the felspar, is also in progress, and this mineral, with the garnet and cloudy saussuritic products, completely replaces the original plagioclase. The cleavage of the felspar is preserved in the pseudomorph, even though it has become merely a patchwork of brightly polarising, variously oriented prehnite-grains. This mode of occurrence of prehnite, is considered by Weinschenk (Petrographic Methods, p.299) to be the same form described as lotrite by Murgoci.

Another type of saussurite-gabbro is shown by M.B., 181, from south of Gulf Creek. It is quite similar in appearance to the other saussurite-gabbros, but differs in the presence of coarsely crystallised clinozoisite. The rock, as a whole, is extensively altered. The diallage is sometimes bent, but may remain otherwise unaltered, or have passed into tremolite, and, locally, still further into fibrous and platy serpentine. This last passes parallel

* The saussurite-gabbro, described by Prof. Bonney from the Saasthal, shows also this feature, of a garnet-border to the pyroxenes. See Phil. Mag. 1892, p.243. 
to the vertical axis of the diallage up into veins, where it becomes twisted and irregular. Sometimes it is without definite orientation, and exhibits the thorn-structure. The clinozoisite occurs in isolated grains, and is very irregularly distributed. The grains are unusually large, sometimes $2 \mathrm{~mm}$., in length. They are prismatic in habit, usually twinned singly or multiply, and such twinning throws the basal cleavage-lines, on each side, into a herring-bone or zigzag pattern. Optically, it is distinguished by its high refractive index, low anomalous birefringence, low extinction, and large, optical, axial angle. The grains are usually surrounded by prehnite (Plate xxvi., fig.11).

South of Bingara, there are a number of other peculiar modifications of gabbro. In the field, they are remarkable for their density; they are either greenish-white in character, or translucent and grey, and are spotted with greyish or greenish serpentine-masses pseudomorphous after pyroxene. M.B., 36, of the translucent grey type, has a specific gravity of $3 \cdot 420$, while that of the unaltered gabbro, N.T., 118, is 2.930. The rock consists entirely of garnet locally darkened by the segregation of dusty particles. It contains lakelets of antigorite representing the residue of the original pyroxenes, for there can be no doubt that the garnet has encroached considerably on the pyroxene-boundaries. The chemical composition of this rock is given in Table iii. The whitish rocks $[e . g .$, M.B., 43] differ from this, in that there is a considerable development of prehnite in little scales, quite invisible in ordinary light.

The garnet-gabbros are also developed at Bowling Alley Point, as for instance, N.T., 261, which consists of minute grains of colourless garnet and serpentine. In this connection may be mentioned Mr. Porter's discovery of well crystallised, colourless garnet (topazolite) in the serpentine of Sheep Station Creek, in the same neighbourhood.

A most interesting slide [N.T., 486] from the mass east of Cobbadah, shows that decomposition of the pyroxene is not an essential part of the process of garnet-making. The rock, which is aphanitic, pale green and translucent, consists of a few distorted, but otherwise unaltered diallage-crystals in a ground-mass 
of translucent, finely divided prehnite developing at the expense of the colourless garnet, which forms the ground-mass.

This garnet-rock is, doubtless, that described by Professor $\operatorname{Judd}(\mathbf{4 2})$ as forming a vein near Bingara; and which has been compared by Professor Marshall to the grossularite-diallage rock from the Dun Mountain, New Zealand, which he has termed rodingite(43). The comparative study of some of his material, as well as chemical analysis, shows the correctness of this identification, but I cannot concur in Professor Marshall's views as to the origin of this rock. Abandoning his former view, that they were gabbros modified by absorption of limestone(44), he now considers them to have crystallised out in their present state; and he compares them with the ariègite group of garnet-peridotites. I have studied Professor Lacroix's type-collection of ariègites, and cannot see that they resemble rodingite at all. The long series of alterations of eucrite recorded above, and the regular increase in specific gravities, show clearly that the grossularite-rock is an extremely altered form of eucrite. It often occurs with prehnite, as seen above, and as recorded by Marshall. The Bingara rodingite occurs among saussuritic eucrites, but, until field-evidence has been more fully studied, I cannot suggest how they have become so altered. It was certainly not by absorption of limestone.

A final and entirely different manner of alteration is shown by M.B., 51, from Upper Bingara. In hand-specimens, it appears to be a gabbroid rock that has been highly sheared and veined. Mineralogically, it is altered beyond recognition as a gabbro. It consists chiefly of tremolite aggregated in ragged, multiplytwinned plates. These have a rough parallelism with a single shearing direction, but are locally contorted and interwoven. They are set in a ground-mass of clear albite-felspar, occasionally showing bent, multiple twinning. The rest of the rock is made up of large veins of prehnite.

The various changes in the gabbros, that have been described, are usually those considered as taking place under pressure. Besides the very frequent distortion which the altered rocks have suffered, an interesting confirmation is obtained by the 
gradual increase in density. The following table shows the condition and density of a number of specimens so chosen that the proportion between pyroxene and felspar should be, as far as possible, equal in each, to exemplify truly the change in rockdensity.

TABLE SHOWING THE INCREASE IN THE DENSITY OF THE GabBRo WITH INCREASING METAMORPHISM.

\begin{tabular}{|c|c|c|}
\hline Rock. & Nature. & Density. \\
\hline N T., 118 & 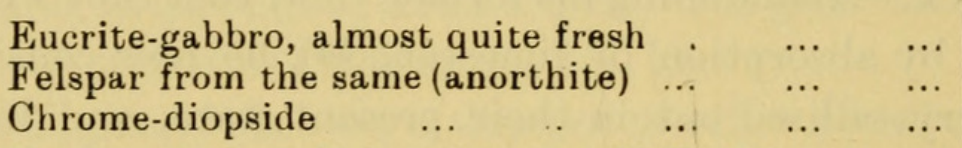 & $\begin{array}{l}2 \cdot 930 \\
2 \cdot 751 \\
3 \cdot 202\end{array}$ \\
\hline M.B., 181 & $\begin{array}{l}\text { Rock much more felspathic than N.T., 118, entirely } \\
\text { changed, with formation of saussurite, a little } \\
\text { prehnite aud scattered crystals of clinozoisite... }\end{array}$ & $2 \cdot 823$ \\
\hline N.'T', 417 & $\begin{array}{l}\text { Rock with less pyroxene than N.T., } 118 \text {, and this } \\
\text { changed to serpentine; the felspar is saussurite } \\
\text { with commencement of formation of garnet } \ldots\end{array}$ & $2 \cdot 945$ \\
\hline N.T., 477 & $\begin{array}{c}\text { Gabbro rich in pyroxene, with saussuritised felspar } \\
\text { and prehnite... } \quad \ldots \quad \ldots \quad \ldots \quad \ldots\end{array}$ & 3.001 \\
\hline M.В., 17 & 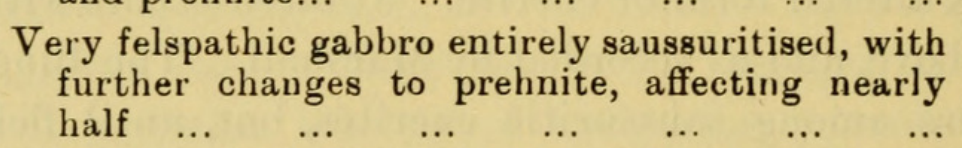 & 3.011 \\
\hline N.'T', , 486 & $\begin{array}{l}\text { Rock in which the felspar is almost entirely } \\
\text { changed to grossularite, which is passing in } \\
\text { turn into prehnite; but the pyroxene is un- } \\
\text { altered } \quad \ldots \quad \ldots \quad \ldots \quad \ldots \quad \ldots\end{array}$ & $3 \cdot 194$ \\
\hline $\begin{array}{l}\text { M. B., } 43 \\
\text { M.B., } 36\end{array}$ & $\begin{array}{l}\text { Rock almost entirely garnet, with a minor amount } \\
\text { of prehnite } \ldots \\
\text { Garnet-rock, with a very little serpentine... }\end{array}$ & $\begin{array}{l}3 \cdot 352 \\
3 \cdot 420\end{array}$ \\
\hline & $\begin{array}{lllll}\ldots & \ldots & \ldots & \ldots & 2 \cdot 8 \\
\ldots & \ldots & \ldots & \ldots & 3 \cdot 55\end{array}$ & $\begin{array}{l}\text { to } 2 \cdot 95 \\
\text { to } 3 \cdot 66\end{array}$ \\
\hline M. B., 51 & $\begin{array}{c}\text { Highly crushed gabbro, composed of tremolite, } \\
\text { prehnite, and albite }\end{array}$ & $2 \cdot 940$ \\
\hline
\end{tabular}

$(7 a)$. The post-peridotite dolerites differ in microscopical characters from the earlier dolerites, They have been most studied between the Paling Yard and Crow Mountain, and as yet their equivalents have not been discovered in the Nundle district. They vary considerably in character. Some are intimately associated with the gabbros and peridotites, and have suffered the same alterations to grossularite- and prehnite-bearing types 
as are seen among the gabbros, with which they are probably genetically connected. A series of rock exist, however, which show increasing amounts of quartz, and approach to a panidiomorphic structure, thus exhibiting some resemblance to certain of the lamprophyres.

The following may be considered as typical examples-M.B., 225 : intrusive into the serpentine, five miles south of Crow Mountain. In hand-specimen resembling the Nundle dolerites, medium grain-size, and dark greyish-green colour, with grey and pinkish felspars. It consists of rough idiomorphic augite, making up about one-half the rock-mass. It has usually a large, optic, axial angle, but, in one instance, this was only $65^{\circ}$. Hence there may be some excess of the enstatite-molecule present. It is partly converted to actinolite. The felspar is slightly zoned, and is basic andesine; a little orthoclase is present, and possibly a little quartz. A similar rock [M.B., 229] intrudes into the serpentine at Crow Mountain, and is noteworthy for the presence of $x$ clear zone of secondary plagioclase (andesine) around each felspar-prism.

'The dyke of dolerite in the serpentine at the Paling Yard[M.B., 68], and that three miles south of Gulf Creek [M.B., 194], on the eastern side of the serpentine, differ from the above in their greater approach to panidiomorphism, and the abundance of the interstitial quartz, either granular [M.B., 194] or granophyric. Small veins of prehnite occur in the Paling Yard rock.

There are others, however, which are quite free from quartz. A dyke in the serpentine on Eumur Creek [M.B., 198] consists of plagioclase, and small, roughly idiomorphic augite, giving a granulitic structure. This felspar is very clear, and the augite quite undecomposed. It occasionally has sahlite-striation, but the optic, axial angle is always large. Veins of prehnite are abundant, and small, isolated patches of the same mineral occur throughout the rock. A little pennine and titanomorphite are also present. M.B., 187, from the same locality, appears exactly similar in ordinary light, save for the greater roughness of the 
colourless portion. This is due to the fact, that the whole of the felspar has been replaced by prehnite, which forms very irregularly shaped, interlocking patches. The crushing of the rock has induced a very undulose, sometimes anomalous, extinction in the prehnite, making its determination difficult. In unstrained areas, and especially on the borders of the slide, where the cleavage shows better, the following observations were made, which determine the mineral to be prehnite. The refractive index is greater than anorthite, but less than pyroxene, the extinction being parallel to the cleavage. The optical character is positive, the optic, axial angle slightly greater than $125^{\circ}$, and the axial plane is perpendicular to the cleavage. The double refraction-colours are often low, but tints, higher than those of the highest colour for the diallage, have been observed. Sometimes rocks such as this are porphyritic, with prehnite as phenocrysts, e.g., M.B., 236, a dyke on Crow Mountain.

Another curious rock forms a dyke in the serpentine on the road near Wood's Reef [M.B., 83]. It forms a dense, red, weathering skin on an interior of hard, aphanitic, buff-coloured rock. 'This consists of small twinned pyroxenes, sometimes with the herring-bone structure, lying in a ground-mass of finely granular, almost homogeneous garnet. A similar but more coarsegrained rock, [M.B., 28] differs in being pale green in colour; the garnet is clouded with dusty, oblong areas, both large and small, the appearance of which strongly suggests that they represent the original felspar-laths and phenocrysts. The rock was probably somewhat sheared before its alteration.

Finally may be mentioned, a dyke-rock [M.B., 185] occurring at Paling Yard. It is greenish, recalling a dunite, but consists of kaolinised felspar with secondary albite, epidote, and streaks of chlorite.

The mineralogical changes in these rocks are closely analogous to those that have been undergone by the gabbros, and are clearly pressure-effects, which, as will be seen, have not been suffered by any subsequent rocks to anything like such an extent, It must, therefore, be taken that these dolerites were closely associated 
with the serpentine and gabbro intrusions, and modified by the same dynamic action as these. They are to be sharply separated, therefore, from the entirely distinct dolerites of the Blue Knob group.

In Dr. Bonney's collection are some specimens indistinguishable from M.B., 83, described above, which were obtained by Dr. J. M. Bell, from the Serpentine Belt, Narsatas Hill, (Urals?) Siberia. They have not yet been described, and I am much indebted to Dr. Bonney for permission to mention them here.

$(6, b)$. There is a small series of acid dykes intruding into the serpentine at several localities. M.B., 316, occurs near the Devonian limestones, 14 miles south of Bingara. It is a purplishblue in colour, with small, white felspar-phenocrysts. It consists of albite in three forms. The idiomorphic phenocrysts are slightly clouded by decomposition, and twinned on the albite and manebach laws. They are sometimes corroded, and show also straineffects. The ground-mass consists of very finely divided albite in a mosaic, with irregularly shaped patches and lenticles of water-clear, larger crystals. Set all through, are radiating fibrous aggregates of pleochroic pennine, changing from pale purplish-blue to green. There are also numerous, small, irregular fragments of sphene, and some yellow clinochlore.

M.B., 230, which intrudes into the serpentine, south of Eumur Creek, is a paler rock. It consists of large, strained albitecrystals, with more or less granulated edges, lying in a mosaic of highly strained, interlocking quartz-grains. A very little of the fibrous pennine is also present. In M.B., 21, the granulation has proceeded still further, and the felspars are almost entirely replaced by exceedingly, minutely powdered albite, lying in a mass of larger, recrystallised but strained quartzes. Where still intact, the albite is passing into tiny flakes of mica. The pennine is absent, but small strings of granular diopside(?) occur. There are also a few grains of rutile. This specimen is a hard, white, granular rock, occurring near the limestone and serpentine at Spring Creek, Bingara, in such a way as to seem an alterationproduct of the marble produced by the peridotite-intrusion. The 
microscope, however, shows that it must be a dyke later than either.

The presence of albite-bearing dykes, in the serpentine, calls for some remark. Prof. Lacroix(28) instances dykes similar to the above, accompanying the ultrabasic rocks, in support of his contention that the ultrabasic magmas gave out alkaline emanations. The "granite" of Gew Graze, at the Lizard(40), which is changed locally into pseudophite, is very similar in microscopical appearance, and contains identical needles of pale green pennine. Similar rocks again occur in the Serpentine Belt at Narsatas Hill, Siberia, where it was found by Dr. J. M. Bell. The slices studied were found in the collection of Dr. Bonney, by whose kind permission they are here noted. The association of serpentine with sodic solutions may possibly account for the production of glaucophane in the sediments altered by the intrusion of the peridotite at Angel Island, California(49).

(8). So far as they have been examined, the dolerites and dolerite-porphyrites of the Blue Knob group of intrusions are a fairly homogeneous series of rocks within certain limits. They are quite different in character from both the older dolerites, and the post-peridotite group of rocks, and are probably younger than either.

The typical dolerite of the Blue Knob laccolite [M., 312] is a medium-grained rock, composed chiefly of idiomorphic labradorite, which is strongly zoned, and clouded with epidote and probably zoisite. With this is a large amount of idiomorphic augite, partly quite fresh and pale yellow in colour, but, in the main, completely decomposed to bright yellow-green chlorite. Large grains of ilmenite are abundant. Between the crystals, there is a small amount of more finely crystallised matter. This consists of quartz, decomposed felspar, and abundant, small crystals of apatite, which mineral does not occur in the plagioclase-phenocrysts, except in their outer edges.

The porphyrites occur in the narrower intrusions, dykes, and sills. As typical of these, M.B.,326, may be described. It occurs on the main road, two miles south of Cobbadah. It is a handsome rock, with a fine-grained, dark green ground-mass, a few 
darker augite-phenocrysts, and abundant, pale green crystals of plagioclase, $3 \mathrm{~mm}$. in diameter, showing zonary banding very distinctly. This is labradorite. The augite-phenocrysts have passed into peculiar, spherulitic masses of chlorite. The groundmass is finely crystallised, lathy andesine, with a little epidote and chlorite, and much leucoxene. Some pyrites is present. Occasionally, the rock is very rich in veins and spherules of white prehnite, as in M.B., 64 , from the intrusions on the Manilla River at Plumthorpe, 10 miles west of Barraba.

Possibly there should be classed with this group M.B., 285, a purplish-green rock forming a narrow band in the mudstone one mile west of Eulowrie homestead, on the Horton River. It consists of large and small phenocrysts of zoned plagioclase, with pseudomorphs of calcite and chlorite after a pyroxene, possibly hypersthene, though they are not unlike the augite-pseudomorphs in the Blue Knob dolerite. The ground-mass is quite subordinate. It consists of orthophyric plagioclase-crystals, with a little augite and some magnetite, set in a small amount of glassy base.

(9). Granites, Granodiorites, and Porphyries.-The grouping in order of age, given in Part i., was as under :-

(a) Felsites, etc., of the Bingara District.

(b) Granodiorites of Nundle and their associated porphyries.

(c) Sphene-granites of Moonbi.

(d) Tingha granite.

(e) Acid granite.

( $f$ ) Tourmaline-granite.

(a) An example of this group occurs near the Ruby Hill basaltneck, south of Bingara. Mr. Pittman describes it as a microcrystalline quartz-felsite.

(b) The chief feature of the second group is the immense number and variety of the porphyritic apophyses. As typical of the plutonic members, are described N.T., 384, from the upper end of Duncan's Creek, and N.T., 413, from Mt. Ephraim. The former has a hypidiomorphic, granular texture, and consists of zoned oligoclase-andesine, a very little orthoclase, abundant quartz showing 
strain-effect, biotite (slightly chloritised, with haloed zircon-inclusions), twinned hornblende sometimes idiomorphic, well crystallised magnetite, and apatite, together with a little secondary epidote. This may clearly be classed as a granodiorite. N.T., 413, will fall into the same group, though it differs in its smaller grainsize, greater amount of orthoclase, absence of hornblende, rarity of magnetite, and presence of a little sphene. The grain-size is less regular, and the orthoclase occurs in a few large grains poikilitically enclosing quartz and plagioclase.

Of the apophyses, the most striking are the black felspar-porphyries, or malchites. These are very abundant, especially east of Munro's Creek. They have a dark, aphanitic ground-mass, with white phenocrysts of plagioclase, and sometimes smaller, dark phenocrysts of hornblende. Microscopically, the rocks are seen to consist of idiomorphic prisms of brown hornblende, with usually small, fibrous extensions of actinolite, as described by Cross. The felspar is also idiomorphic; it is zoned and twinned on the albite, pericline, carlsbad, and (rarely) manebach laws; its average composition varies from acid labradorite to basic oligoclase. It is often much decomposed, with formation of zoisite, sericite, etc. The ground-mass is exceedingly fine-grained, consisting of lathy or granular plagioclase crowded with very minute, but perfect hornblende-prisms. Some magnetite is present in the phenocrysts and ground-mass. Sometimes a little biotite is present. In N.T., 89, is a large, chloritising flake encircled by small hornblende-prisms. This interesting specimen shows also a contact-surface with the spilites and the edge of the epidote-veins in these basic rocks. A vein in the spilite stops short at the boundary of the porphyry. Along the surface of contact, there is a zone only $2 \mathrm{~mm}$. thick, crowded with phenocrysts with general flow-direction. In places, a small vein of quartz appears in the actual line of contact (Plate xxvii., Fig. 13).

Sometimes these porphyries are entirely decomposed (e.g., N.T., 62 ), and are then dense, cream-coloured rocks, in which the original hornblende is represented by limonite-pseudomorphs. 
Related to these rocks, are two other groups of porphyries. The first group may be termed the grey porphyries, being less dark than the last group. They are very frequent about the head of Munro's Creek, and are characterised by the more coarsely crystalline nature of the felsitic base. The felspar-phenocrysts are generally smaller and often fresh. The hornblende is usually much smaller, and is considerably decomposed to chlorite, or to chlorite, biotite, and calcite [N.T., 82], and the secondary material is distributed about the rock. In one [N.T., 33], hornblende forms long, faintly coloured prisms of a brownish-pink tint, and decomposes to redbrown chlorite. There is often apatite noticeably present, and quartz is not infrequent in the base, and occurs occasionally as xenocrysts [N.T., 82]. The ground-mass is usually a mosaie of irregularly granular material, but sometimes [N.T., 319], it is pilotaxitic. This last rock is remarkable in containing a little pyrite. Its porphyritic character is not pronounced, and still less so is that of N.T., 387, which has quite a schistose appearance in hand-specimen. Orthoclase is present in these rocks, but only in small amount.

A second variation is afforded by the granophyric porphyries, in which there is a considerable amount of micrographic structure. A regular sequence can be traced, from rocks in which spherulitic structure is just suggested in the base mosaic [N.T., 42, 99], to those in which it becomes well marked in the base [N.T., 142, 516]; and. finally, to those rocks in which the whole base is granophyric, and set with seriate* phenocrysts of plagioclase. In this rock, biotite replaces hornblende.

The quartz-porphyries have also their fine- and coarse-grained varieties. Several, very fine-grained examples occur on the watershed between Duncan's and Munro's Creeks. They are grey or creamy-pink in colour, and consist of more or less idiomorphic quartz-grains often strained, in a micro-felsitic base, which some-

* A useful term suggested by Iddings. 
times shows strong fluxional arrangement [e.g., N.T., 87]. The rocks are almost free from ferromagnesian minerals, or may contain a small amount of biotite. Finally, there is a rock [N.T., 404] occurring on the same ridge, composed of rounded grains of quartz and acid plagioclase about $1 \mathrm{~mm}$. in diameter, with a very little, fine-grained base. It may be considered a soda-aplite.

(c) The sphene-granites of Moonbi have been described by $\mathrm{Mr}$. G. W. Card(18, p.210). Summarising his remarks, the rock is not conspicuously porphyritic. It contains hornblende and biotite, with a tendency to segregate with magnetite into basic patches. Sphene is plentiful. Felspars predominate, with orthoclase and plagioclase in varying proportion, the latter zoned oligoclase. Quartz is not very abundant. An analysis is given of the granite from Walcha Road, a portion of the same massif (Table iii., p. 706).

These granites also extend northwards from Tamworth to Attunga, and, in Horsearm Creek, many basic segregations were noticed by the present writer. In these, the colourless and coloured minerals are present in about equal amounts. Orthoclase and oligoclase are about equal, quartz is rather less abundant. The predominant, coloured constituent is biotite, which contains a little zircon. Almost colourless augite is rather subordinate, and decomposes peripherally to actinolite. A little magnetite is present in small cubes.

$(d),(e),(f)$ The Tingha granite $(d)$, and the acid tin-bearing granites occur near the great bend on the Gwydir River, 30 miles south-east of Bingara. They have been described by Mr. Andrews and Mr. Cotton. Mr. Andrews classes the Bendemeer granite with the acid granite(18, p.212, 219; 19, p.742).

The Tingha granite is porphyritic with plagioclase and quartz phenocrysts, with biotite, hornblende and accessory apatite, and a second generation of quartz and felspar in the base. Local modifications are very porphyritic, and contain pegmatites and tourmaline felsite dykes. The acid granites are coarsely crystalline, consisting of quartz and orthoclase, with sometimes a little biotite and 
magnetite. Mr. Cotton, at first, classed the tourmaline-granites as a modification of the acid granites (op. cit.), but he now considers them to be a separate intrusion. He found them near Tingha. Mr. Stonier has reported them to occur "east of Bingara," and the present writer found them near New England Creek, east of Manilla, 50 miles south of Tingha.

(10) The lamprophyric rocks are of uncertain age and affinities They intrude into Devonian, and probably Carboniferous rocks, forming small dykes, and all the occurrences noted are within a few miles of the serpentine-belt. In the absence of definite evidence to the contrary, they will be considered to be a late phase of the granitic intrusion, as is usual. The rocks collected, show a considerable range of character, and may be referred to several types. The minettes are represented by M.B., 145, occurring in a dyke near the contact of granite and serpentine at Attunga. It is a dark, medium to fine-grained rock, with glistening mica-plates. It contained abundant idiomorphic biotite, decomposing with separation of magnetite and diopside in well defined prisms, slightly uralitised. The felspathic constituent is chiefly orthoclase in singly twinned prisms or more irregular grains, while a minor amount of oligoclase is present. Interstitial quartz occurs in small amount, and apatite is abundant. There is a little secondary calcite. The analysis indicates the strongly potassic character of the rock (Table iii.).

A very fine minette [M.B., 200] pecurs about one-quarter of a mile south-west of Eumbra homestead, Crow Mountain(Plate xxvil., Fig. 14). It forms a small intrusion in the mudstone, beside an intrusion of dolerite, but the relation of the rocks to each other has not been ascertained. Unfortunately, the minette is very decomposed and friable. It consists of coarsely granular orthoclase, and abundant, hexagonal plates of strongly pleochroic biotite, containing minute zircons. Small, idiomorphic prisms of diopside, thick needles of apatite, and a very little interstitial quartz are also present.

The vosgesites are more abundant, and have been found on the Frenchman's Spur, near Nundle [N.T., 190, 317], and on Tom 
Tiger Hill, opposite N.T., 390 ; on Wiseman's Arm Creek, north of Attunga [M.B., 144], on Bungemullagalarno Peak [M.B., 275], and north of Namoi River. They are fine-grained rocks, usually pink in colour, with abundant, small crystals of green hornblende. Rarely, in the freshest specimens, they are grey. Microscopically, they are seen to be chiefly composed of lath-like felspar, orthoclase dominating over plagioclase, while there is a good deal of interstitial quartz. The hornblende-prisms are up to $2 \mathrm{~mm}$. in length, and are passing into chlorite. A little apatite and magnetite occur, also a small amount of secondary calcite.

Augite-vosgesite occurs on Deep Lead Creek, Mt. Sheba [N.T., 207]. It is a light greenish-grey, fine-grained rock, with patches of dark chlorite, which weathers easily, giving a pitted surface. It consists of idiomorphic, thick, fresh prisms of augite, about $1 \mathrm{~mm}$. in length, set in a very fine-grained ground-mass of thin augiteprisms, and plates of chloritised biotite, on a background of felspar, chiefly orthoclase, and a little quartz. Some calcite is present, and masses of chlorite, with quartz and calcite, occur, probably replacing augite.

N.T., 77, which occurs as a dyke on the slope east of the Peel River, three miles south of Bowling Alley Point(Moonlight Creek), may be classed as an odinite, though differing in some respects from the type-rock. It consists of a network of acid plagioclasecrystals, generally rather elongated, and sometimes $1 \mathrm{~mm}$. in length. There is a considerable amount of interstitial quartz. The ferromagnesian mineral was chiefly hornblende, in long, thin prisms, but it is now almost entirely decomposed to chlorite and earbonates.

A beautiful camptonite [M.B., 228] was found, unfortunately not in situ, but as a boulder by the Manilla track, four miles south of Crow Mountain. It is dark blue-black, fine-grained, and has glistening mica-plates. It consists of small, idiomorphic erystals of diopside, vivid brown biotite-plates, and large olivine-crystals, the last completely replaced by quartz, carbonates, and pilite. There is a little magnetite. The ground-mass is composed of finely 
granular plagioclase, with abundant, small crystals of apatite (Plate xxvii., Fig. 15).

(11) The alkaline rocks of the Nandewar Mountains have been described in detail by Dr. Jensen(9). He considers them to be of Eocene age, and he determined the occurrence of the following types:-

Volcanic - alkaline rhyolite, trachytes, phonolites, alkaline andesites, and basalts.

Hypabyssal-alkaline syenite-porphyry, pulaskite-porphyry, augite-porphyrites and teschenites, monchiquitic lamprophyres.

(12a) The Tertiary basalts are of several varieties. In general, they are normal, fine-grained olivine-basalts, quite holocrystalline and undecomposed. In other places, they are hypocrystalline, and, east of Hanging Rock, some layers of very decomposed basaltscoria have been discovered. There are also more coarsely grained and porphyritic types. For convenience, we will describe the Nundle and Barraba basalts separately, as they present somewhat different features, and are possibly not of the same age.

The following rocks are the most typical of those developed in the northern district. M.B., 75, which occurs four miles east of Barraba, and forms portion of the Bell's Mountain flow, is a medium-grained, holocrystalline rock, with well developed ophitic structure, consisting of laths of andesine, faintly purple augite, small olivine-grains, well formed ilmenite-plates, long apatiteneedles, and a few minute flakes of biotite. M.B., 193, occurred in Chain of Ponds Creek, eight miles north-west of Barraba. It was not in situ. It is a fine-grained rock, with a pilotaxitic texture, composed of labradorite-laths, olivine, granular augite, platy ilmenite, and apatite-needles. In this matrix are large, clear crystals of bytownite, free from schiller-plates, and considerably corroded. Here and there, felspar has been secondarily deposited on the previously corroded surface. These large crystals are not zoned, and are probably xenocrysts, though it is not impossible that they should have been derived from the magma by an intratelluric crys- 
tallisation. M.B., 341, which covers the auriferous gravels of TeaTree Gully, is a fine-grained rock, with small olivine-crystals visible in hand-specimen. It consists of idiomorphic laths of basic labradorite, olivine, and numerous smaller grains of augite. There is a considerable amount of dark groundmass, which contains, in a glassy base, microlites and skeleton-crystals of felspar, augiteneedles, and abundant, minute plates of ilmenite standing perpendicularly to the crystal-surfaces of the earlier-formed crystals and the microlites. As noticed by Mr. Card, in his description of the basalts overlying the diatomaceous earths near Chain of Ponds Creek(32a), all these basalts are remarkably fresh, a fact supporting their comparatively recent extrusion.

The basaltic neck in the Hall's Creek Valley, near Bingara ("Ruby Hill"), has been described petrologically by Mr. Card(45), from specimens collected by Mr. Pittman. He drew attention to the occurrence, in it, of an eclogite, with kelyphitically bordered garnet, and omphacite which was included in the basalt, either in tragments of rock (xenoliths), or in isolated xenocrysts. The basalt rises up, in dykes, through a breccia, with fragments and xenocrysts from the same rock.

The basalts of the Nundle region are also varied. The finegrained rocks may be divided into two types, the granular, and the fluidal. The granular rocks have a rough surface on weathering, and break with a hackly fracture, appearing to be an aggregate of pellets of basalt, rather than a simple rock. Some rocks can be divided into granular masses of the size of small peas, e.g., N.T., 160 , which occurs on the Yerrowinn-flow, one mile west of the summit. Microscopically, this rock shows no sign of such a structure; it is a normal, fine-grained rock, consisting of very small felsparlaths, augite-prisms, magnetite-cubes and octahedra, and larger crystals of olivine, decomposing with the formation of limonite. Here and there are inclusions of a rather more coarsely-grained, ophitic basalt, in which the olivine is in tiny, ovoid grains. The

* Rec. Geol. Surv. N.S.W. 1897, Vol. v., Part 3, p.20. 
main basalt shows a cooling rim of more dense crystallisation about such inclusions. The fluidal basalts have a smooth weathering surface, break with a more regular fracture, and atmospheric corrosion etches out the flow-lines as they twist round xenocrysts, or pass regularly through the rock [N.T., 174]. Microscopically, these are distinctly fluidal, the felspar-laths have a general direction, the magnetite and augite of the base are very minute indeed, while the olivine-crystals are larger. They are decomposing into bowlingite. Fluxional structure is also seen in the bending of the rock, in zones of slightly different grain-size, and the enrichment of some zones in magnetite. There are small inclusions of coarsegrained rock, chiefly composed of felspar-laths and ilmenite, while large xenocrysts of olivine are visible in hand-specimens.

Other normal basalts occur, without this granular or fluidal structure, and, in them, the usual nodules of olivine-enstatite and picotite occur, together with large grains of pleonaste(?) nearly half an inch in diameter.

Associated with these basalts are some dolerites very rich in chlorite, occurring south and east of Sheba Mountain. As an example, N.T., 171, may be described. It is subophitic in texture, with medium grain-size. About half the augite is replaced by a yellow-green aggregate of chlorite-spherulites, surrounded by a double layer of chlorite, the inner, green, the outer, brown. These consist of minute fibres standing perpendicularly to the enclosing and included laths of felspar. The augite is purplish, and there are a few pseudomorphs after olivine. Ilmenite and apatite occur in small amount. Other rocks differ in the presence of one chlorite layer only.

The interesting alkaline rocks of the Nundle district, and similar rocks in the Mount Royal Range, have been already described by the present writer, and reasons have been given for considering that they occur as sills in the Tertiary basalt(14). A few more particulars may now be given.

The rock capping Square Top Hill, three miles west of Nundle, is dark grey in hand-specimens, with purple-brown augites, and, 
on weathered surfaces, white felspar-laths can be distinguished. Microscopically, the augites are seen to be strongly zoned, purplish and weakly pleochroic in the centre, greyish-green in the outermost portion. The outer zone is usually full of irregular cavities, probably originally filled with liquid, while fragments of felspar, olivine and magnetite are also present. Numerous small phenocrysts of olivine occur and well shaped cubes of magnetite. Occasionally, there are long black rods composed chiefly of minute magnetite-crystals, which are, possibly, decomposed crystals of hornblende. The ground-mass consists essentially of plagioclase, sanidine and nepheline, the last being very abundant. The plagioclase varies considerably in amount. In N.T., 414, though subordinate, it is present in notable amount, and has the composition of sanidine; but in another example, N.T., 418, very little is present, and sanidine is more abundant. In addition, there are numerous, small prisms of augite and apatite, magnetite and chlorite forming, with sanidine microlites, small aggregates interstitial in the base of the rock. In some rocks, more or less natrolite is present, forming small, dusty patches. The rock, which is clearly to be classed as a nepheline-basanite, may pass into a nepheline-basalt, when the plagioclase is not developed. The chemical composition of N.T., 418, is given in Table iii.

The coarse-grained dolerites of the Peel River gravels have been further studied, and their description, as originally given, is here slightly modified. They consist of large, purple phenocrysts of augite, sometimes half an inch in diameter, strongly pleochroic, and not infrequently containing laths of plagioclase, and olivinegrains. Olivine-phenocrysts occur also, smaller, and subordinate to the augite. Ilmenite is abundant, and apatite is present in small amount. Green ægyrine-augite, of the second generation, forms in the base, in small but long, ragged prisms. The felspar forms irregular tabulæ, and is andesine. Interstitially, there are masses of chlorite-stained analcite and natrolite, associated with minute laths of sanidine, apatite, and green augite. The mineral, here stated to be analcite, is the brown, platy mineral of zeolitic nature, mentioned in the Preliminary Note. The dolerites have, then, 
teschenitic characters, and their relation to the basanites is quite obvious.

The rock, N.T., 163, described in the Note as forming a small neck, one mile from Goonoo Goonoo, is of quite similar character, and less decomposed. Analcite, not previously recorded, has since been found, and sanidine and orthoclase are present in small amount. Apatite and abundant ilmenite also occur, the latter often surrounded by tiny mica-plates, perhaps the result of the interaction of the analcite and ilmenite. The augite shows hourglassstructure, and is free from inclusions. Small grains of the second generation are also present. Olivine forms large, fresh crystals. It is possibly better to regard this rock as a teschenite-dolerite than as an essexite. There seems little reason to doubt the primary nature of the analcite.

In the Preliminary Note on these rocks, their extension from Mt. Warrawalong to Nundle was shown, but a large increase in this area can now be indicated. The Prospect essexite near Sydney, recently described by Jevons, Jensen, Süssmilch, and Taylor(46) is, in its nature, related to the essexitic or teschenitic dolerites of Nundle. The analcite-dolerites and essexites described by Jensen, in the Nandewar Mountains [N., 17; N., 28; and N., 57]; (9, pp. $880-883$ ), are clearly of this type, and are found in sills; while the rock of Delungra Peak, near Gragin, 20 miles east of Warialda, described by Mr. Carne and Mr. Card(27), is also one of this series, and is probably similar to that of Mt. Warrawalong in its manner of occurrence. I have also received, from Mr. R. A. Wearne, a specimen from Mt. Melora, near Ipswich, which has proved to be a most beautiful example of teschenite, showing partial replacement of the plagioclases by analeite and natrolite There can be no doubt that it belongs to this intrusive series, and is well worth further investigation. This emphasises the remarks, made formerly, of the close association of these with the Tertiary basalts, and the manner in which they reflect the varying degree of alkalinity of those basalts. The extent now proved for these rocks is nearly 500 miles (Sydney to Ipswich). 
GREAT SERPENTINE BELT OF NEW SOUTH WALES, iii.,

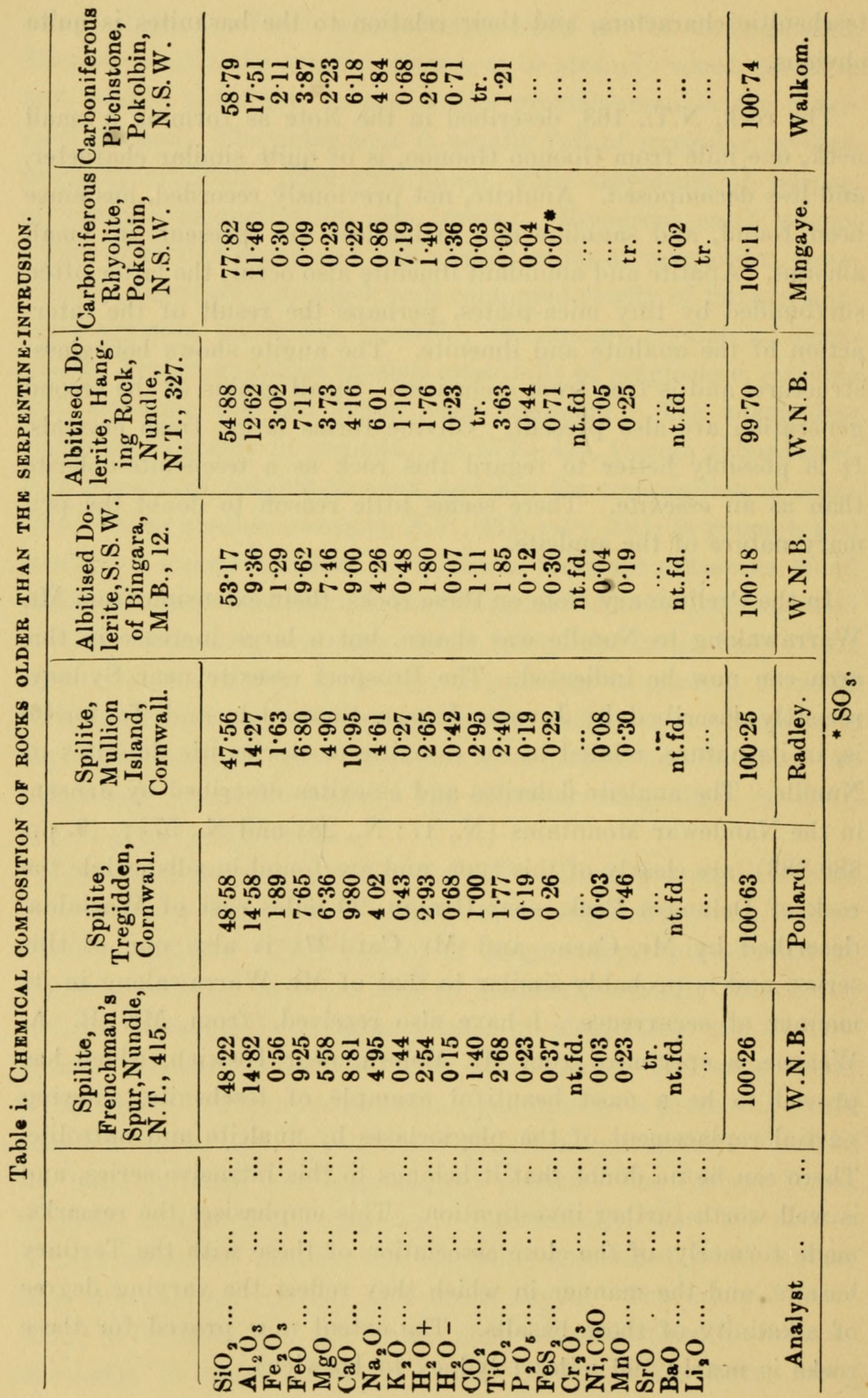




\begin{tabular}{|c|c|c|c|}
\hline 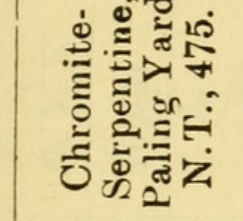 & 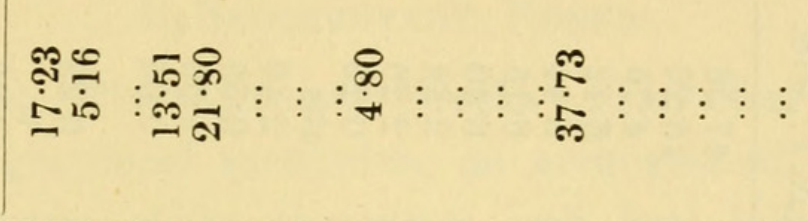 & 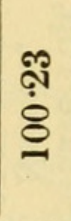 & $\frac{20}{\dot{z}}$ \\
\hline 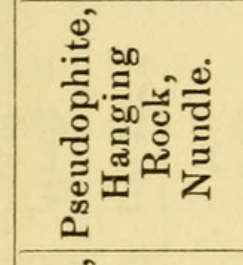 & 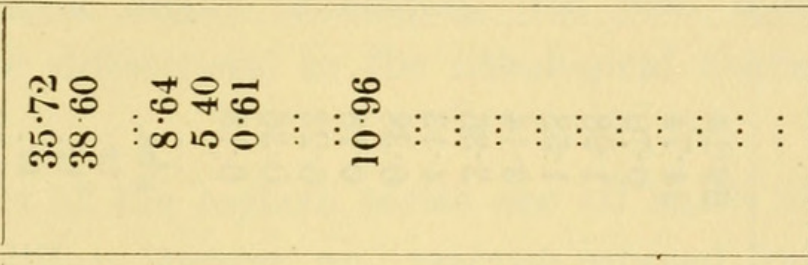 & ๙ூ & $\begin{array}{l}\dot{\Xi} \\
\stackrel{x}{0}\end{array}$ \\
\hline 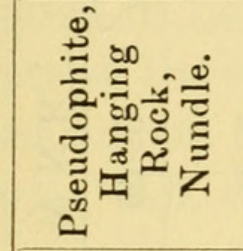 & 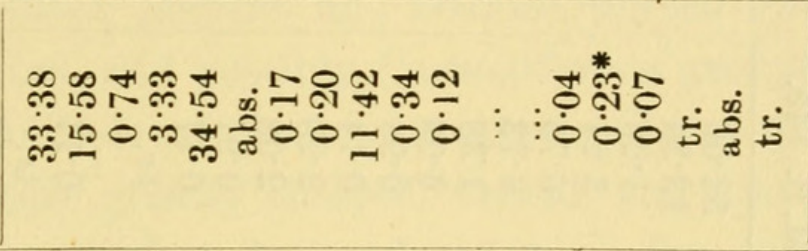 & $\stackrel{\circ}{\dot{8}}$ & 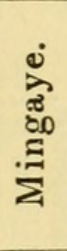 \\
\hline 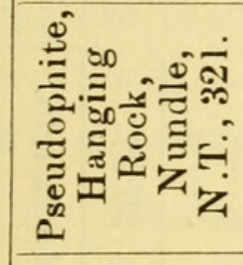 & 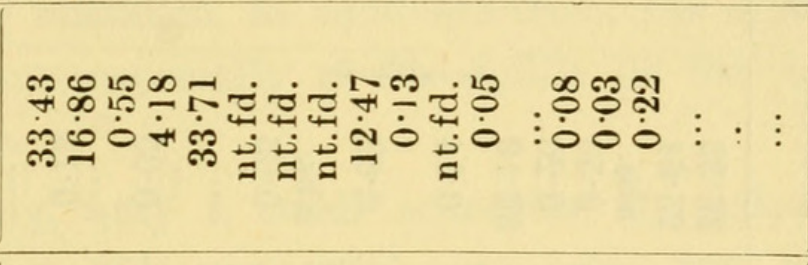 & $\stackrel{\infty}{\stackrel{\infty}{\circ}}$ & $\stackrel{\oplus \dot{c}}{2}$ \\
\hline 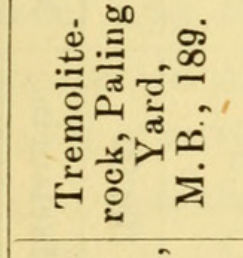 & 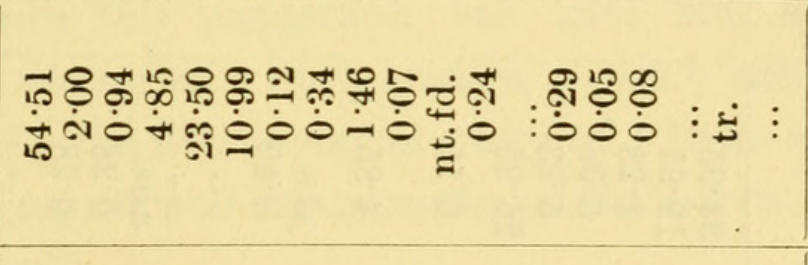 & $\stackrel{9}{\dot{1}}$ & $\begin{array}{l}\stackrel{20}{z} \\
\dot{3}\end{array}$ \\
\hline 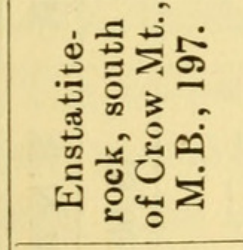 & 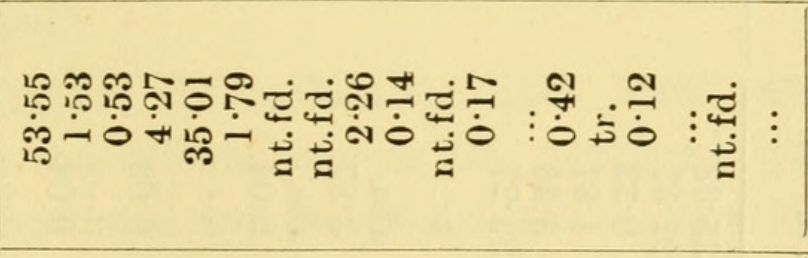 & $\begin{array}{l}\stackrel{\infty}{\infty} \\
\dot{\rho}\end{array}$ & $\begin{array}{l}\stackrel{0}{2} \\
\dot{z} \\
3\end{array}$ \\
\hline 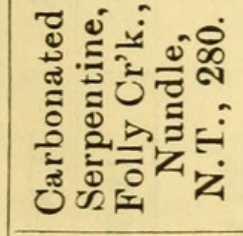 & 究 & $\stackrel{\mathscr{\leftrightarrow}}{\dot{\leftrightarrow}}$ & 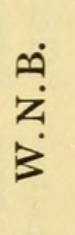 \\
\hline 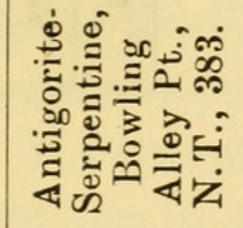 & 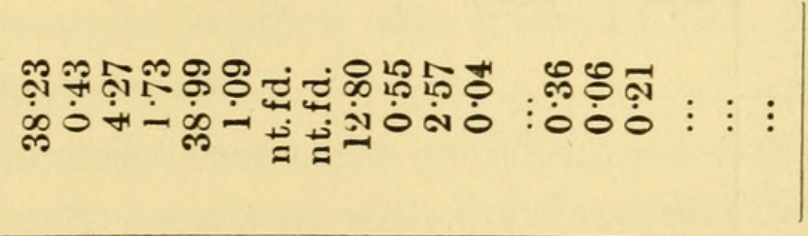 & $\begin{array}{c}\text { भै } \\
\dot{\delta}\end{array}$ & $\sum_{i=1}^{\infty}$ \\
\hline & 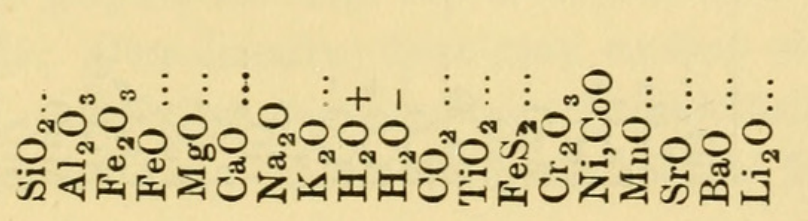 & & $\frac{\overrightarrow{0}}{\overparen{\pi}}$ \\
\hline
\end{tabular}




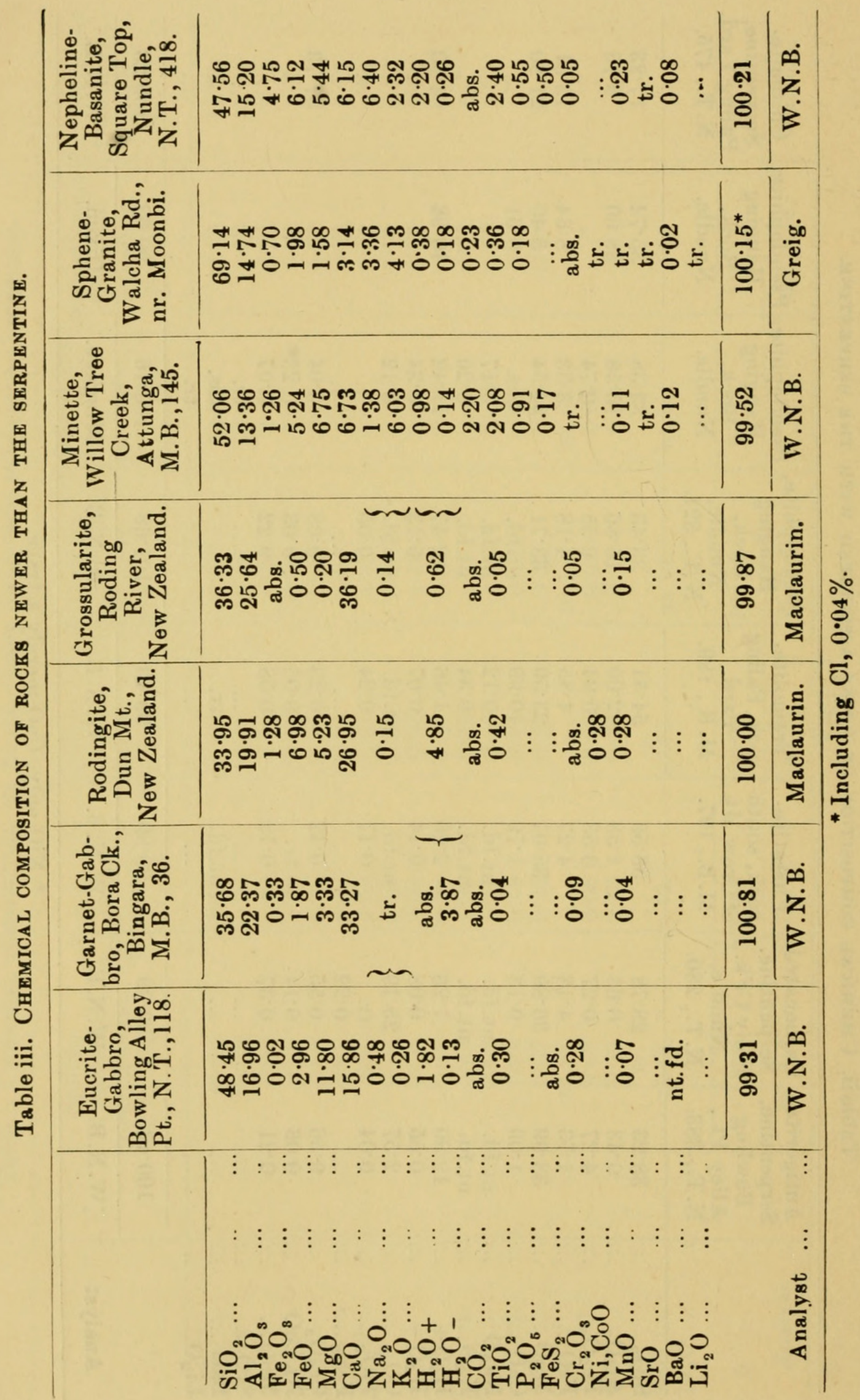




\section{B. Sedimentary Rocks.}

Classification.-The sedimentary rocks will be described in order of their stratigraphical succession, an arrangement which, while necessitating some slight repetition, will best indigate the resemblances and differences, in the lithological characters, of the various series.

(1) The rocks of the eastern series are all much altered. They consist of phyllites, jaspers, and metamorphosed members of the western Devonian, and possibly Carboniferous groups. As before pointed out, spilite-lavas oceur in great abundance throughout this series, and, where greatly sheared, veined, and otherwise altered, they are easily mistaken, in hand-specimen, for altered, sedimentary rocks, more especially if the spilite be one of the highly felspathic type.

Unfortunately, only a small collection of eastern rocks was made, and hence this paragraph can give but an incomplete description of the series. Such studies, as have been made, show that it is only by the microscopical study of a large series of these rocks, that the nature and stratigraphy of the eastern series can be finally elucidated.

The following are the rocks that have been determined, and their probable equivalents, among the unaltered types, are indicated. The mudstones and clay-shales are represented by sericitic phyllites. In the neighbourhood of the red jaspers, these may become more ferruginous, and pass locally into hæmatitic schists. Conglomerates, such as cross the Peel River, south of Nundle, are represented in the narrow band of schistose conglomerate on the Namoi River, near its junction with Ireland Creek. They contain fragments of granite, etc.

The altered breccias, that occur on Wiseman's Arm Creek, M.B., 273, can be clearly correlated with the Tamworth breccias; while green, schistose greywackes may represent the tuffs of the Upper Tamworth beds. Oceasionally, these may contain small, circular or oval areas, suggesting the presence of radiolarian casts. A typical, altered tuff [e.g., M.B., 53; from Woods' Reef] is com- 
posed of crystals of felspar, and grains of quartz, in a fine-grained ground-mass, greatly sheared and decomposed. Some tuffaceous rocks, like M.B., 243, are fine-grained, black, aphanitic, and nonschistose; and consist of fragments of felspar, quartz, spilite, and felsite in a very fine-grained ground-mass. Here and there, lenses of white, saccharoidal marble or limestone occur, usually fairly pure, but sometimes containing a considerable amount of siliceous material in parallel planes of bedding.

The most notable rocks are the jaspers, which occur parallel to the serpentine-belt, all along its length. In several localities, radiolarian casts have been found in them, viz., at Woods' Reef and Bingara, by Messrs. David and Pittman; at Nundle, the Namoi River, and near Warialda by the present writer. The radiolaria occur as chalcedonic casts in a siliceous matrix coloured by extremely finely divided particles of hæmatite. Frequently, the rock is seamed with small veins of chalcedony, and considerably brecciated, radiolarian, and non-radiolarian fragments being pressed together in a most irregular fashion [e.g., N.T., 101, from near Bowling Alley Point]. In places, the jasper-like rocks are banded; for instance, in Gulf Creek, about one mile below the mine, the rock is a yellow and red, banded chert, which proves to consist entirely of radiolarian remains, the faint outlines of the oval patches being just visible. Except for the red colour and the absence of finely divided epidote, etc., this rock is identical with the crushed, radiolarian cherts of Bowling Alley Point.

Here and there along the serpentine-line, now east, now west of the intrusion, are peculiar rocks full of holes, which are clearly due to the dissolving out of limestone-fragments. The insoluble matrix of these, when non-schistose, appears to be identical with the breccias of Tamworth and Bowling Alley Point; and the whole rock is more or less analogous to the limestone-bearing breccias of Moonlight Hill, near Bowling Alley Point. If this be so, a definite horizon is thus obtained, for the commencement of the study of the stratigraphy of the eastern series.

(2) The Tamworth Series consists of radiolarian claystones. cherts, limestones, tuffs, and breccias, with coralline limestone 
The intrusion of granite into this series has further complicated matters, by providing a number of very interesting metamorphic rocks.

The clay-shales and mudstones of the series have been described by Professor David and Mr. Pittman, from the railway-cuttings east of Tamworth. They consist of very finely divided quartz with biotite, chlorite, and a little carbonaceous matter, with some iron-staining; felspar is present in some amount; sometimes, it may be of secondary origin. Occasionally, tourmaline and apatite are present, but rutile is remarkably rare. Frequently, the layers of deposition are very well marked. Radiolaria are present, in some specimens, in enormous abundance, about one million to the cubic inch, according to the above authors. Occasionally, they can be seen with a pocket lens, or even with the naked eye. The rocks are fine-grained, and evenly interbedded with bands of submarine tuff.

The cherts are banded light and darker green in colour, as a rule, though sometimes black. Very little can be determined from these in microscopical examination; they are more or less completely made up of radiolaria. Pressure has frequently forced all these into an oval shape. The material of the radiolaria is chiefly chalcedony, while the ground-mass of the rock contains finely granular quartz, felspar, epidote, and carbonate with or without carbonaceous matter. Analysis of a black chert showed that it contained 91.06 per cent. of silica $(3$, p. 32$)$. These cherts are intimately mixed with tuff; and the peculiar entanglement of chert and tuff, figured by Professor David and Mr. Pittman, is repeated all along the horizon of the cherts. In the neighbourhood of Horsearm Creek, Attunga, these rocks have been metamorphosed by the intruding granite. A considerable variety of specimens may be obtained, but few have been studied as yet. It has been considerably recrystallised, and is now a mosaic of quartz and acid felspar, chiefly water-clear albite, dotted with numerous, small, brown biotite-flakes. The aluminous portion of the rock has been segregated into needles of sillimanite, pale brown in colour, and very abundant. A little magnetite is also present. 
The breccias are generally greenish in colour, and consist of finely divided, volcanic material, with large, angular pieces of radiolarian chert, which are not infrequently much bleached around their edges. A few limestone-fragments are sometimes present. The igneous fragments consist of finely crystallised, vesicular, or hypohyaline spilites and andesites, which are sometimes little more than pumice. The vesicles of the pumice are filled in with calcite, chlorite, and epidote. There are also crystals and grains of plagioclase and augite, that might have been derived from a dolerite, rounded or angular fragments of quartz, rarely a little orthoclase.

The chief difference between the breccias and the tuffs is that the latter are finer-grained, and more usually consist of single minerals than rock-fragments. On the other hand, by increase in size of the fragments, the breccias pass into the agglomerate-type. Radiolaria are sometimes present in these rocks, occasionally perfectly preserved.

The tuffs are more rare in the Tamworth Series than the breccia, but are more important in the rocks of the Nundle Beds; they are greyish or brownish in colour, with an even, medium grain-size, with occasionally larger felspars. They consist of fragments and crystals of andesine, augite, which is decomposing to actinolite and chlorite, less commonly quartz, also fragments of chert, and pilotaxitic and hyalopilitic spilite with chlorite-filled vesicles. The ground-mass consists of finely divided material of the same composition. Occasionally, radiolarian casts are observable. Magnetite, pyrites, epidote, and carbonates are developed to a varying amount. The tuffs differ from one another in the amount of augite and quartz, the perfect crystal-outline, or the fractured or rounded nature of the mineral-grains, the proportion between base and large grains, and the nature of the voleanic rock-fragments. In one tuff, occurring with the limestone at Attunga(M.B., 147), the volcanic fragments are of an extremely basic glass, crowded with dusty magnetite and felspar-microlites. A similar inclusion has been observed in the breccia near Bingara. There are, in addition, a few fragments of the usual type of lava and radiolarian chert. 
The chief mineral-particles are large plagioclase-grains, with a few quartzes, suggesting origin from a grano-dioritic rock.

Where the Moonbi granite intrudes into these rocks, some interesting contact-rocks are developed. They have been crushed, and recrystallised into a fine mosaic of quartz and plagioclase, with larger crystals of the latter mineral. The ferromagnesian portion appears as green hornblende or actinolite. The foreign fragments have suffered more or less alteration. Sometimes, when easily affected, they appear only as minutely comminuted areas, or the quartz-grains are crushed to single, small, clear mosaics. The augite-crystals and grains pass into hornblende, and epidote or clinozoisite is developed. The felspar-fragments generally seem to suffer least, and occasionally they are enlarged. The fragments of spilite are more or less sheared, and their original augite is changed to actinolite. The most advanced stage, in the alteration of these rocks, appears to be the development of long bands of green hornblende, and biotite running irregularly parallel through the finer-grained ground-mass.

Specimens N.T., 460-465, exemplify this series of rocks, which will repay more detailed study.

The limestones of the Tamworth Series are of two kinds. The radiolarian limestone, described by Messrs. David and Pittman, and the purer, coralline limestone. The former, they say, is a dark bluish-grey rock, weathering into a deep chocolate-brown, pulverent crust, with greenish patches. The greater part of the rock is insoluble in hydrochloric acid; no primary quartz is present. In some examples, there are fragments of a chiastolite-bearing clayshale, and patches of chalcedonic quartz. The radiolarian tests have their original substance preserved, in most cases, lie imbedded in calcite, and are filled with the same material. Generally, the tests are broken, the spines and outer tests suffering more than the medullary tests.

Near the Cuerindi homestead, on Hall's Creek (Manilla), a similar, brown, weathering-grey limestone occurs [M.B., 65]. It consists very largely of tuffaceous material, such as fragments of spilite, felspar-crystals, and grains of quartz. 


\section{GREAT SERPENTINE BELT OF NEW SOUTH WALES, iii.,}

The coralline limestone has been described as being of a greyishblue character, near Bowling Alley Point. It is associated with tuffs, and contains a considerable amount of foreign, insoluble matter. In places, it has been entirely swamped by spilites and breccias, and is represented by the occurrence of isolated fragments of limestone, frequently fossiliferous, in these two pyrogenic rocks. Southwards, on Folly Creek, white, crystalline limestone occurs, containing bands of insoluble, siliceous material. Northwards, on Black Jack, the rock is a pinkish, brecciated marble, with much secondary calcite. Further north, white and pink crystalline limestone occurs, near Moonbi, but it is much altered by contact with the granite. Altered limestones, again, occur at Carmichael's farm, east of Tamworth. The crystalline limestones of Tamworth are greyish in colour, and stretch northwards to Attunga, where they are greatly altered by contact with the granite, in two localities. Further northwards, the limestones are unaltered. The few specimens of this limestone that have been analysed, all show a surprisingly small percentage of magnesia. The following are the figures for some of these rocks, obtained from Mr. Carne's "Copper Mining Industry in New South Wales," pp. 325 and $332(47)$.

\begin{tabular}{|c|c|c|c|}
\hline & $\begin{array}{l}\text { Warialda, } \\
\text { Kelly's Gully. }\end{array}$ & $\begin{array}{l}\text { Warialda, } \\
\text { Hamilton's. }\end{array}$ & $\begin{array}{c}\text { Near } \\
\text { Gulf Creek. }\end{array}$ \\
\hline \multirow[t]{2}{*}{$\begin{array}{lll}\mathrm{CaCo}_{3} \quad \ldots & \ldots \\
\mathrm{MgCO}_{3} \text { \& } & \ldots \text { undetermined } \\
\mathrm{Fe}_{2} \mathrm{O}_{3} \text { and } \mathrm{Al}_{2} \mathrm{O}_{3} & \ldots \\
\text { Gangue } & \ldots & \ldots\end{array}$} & $\begin{array}{r}98 \cdot 28 \\
0 \cdot 08 \\
0 \cdot 22 \\
1 \cdot 42\end{array}$ & $\begin{array}{r}98 \cdot 07 \\
0 \cdot 43 \\
0 \cdot 28 \\
1 \cdot 22\end{array}$ & $\begin{array}{r}92 \cdot 35 \\
0 \cdot 37 \\
1 \cdot 60 \\
5 \cdot 68\end{array}$ \\
\hline & 10000 & $100 \cdot 00$ & $100 \cdot 00$ \\
\hline
\end{tabular}

At Moonbi, Tamworth, and Attunga, where the limestone is invaded by granite, some very interesting rocks occur.

The Moonbi rocks form an intricate complex, and, as yet, have been little studied. Besides the altered forms of the more or less pure limestones, there are several rocks which probably originated from calcareous shales. Of these, M.B., 172, and 173, are most 
peculiar. The former contains a ground-mass of tinely-divided quartz and green omphacite, with a little felspar and bands of coarse oligoclase, wollastonite, irregularly shaped diopside and calcite. A few, large, clear plates of seapolite are present. Irregular patches of sieve-like garnet occur in the ground-mass, full of inclusions of diopside, and there is also a little irregularly shaped vesuvianite.

M.B., 173, is a dark green rock, with lighter, yellowish-green patches, containing small aggregates of macroscopic crystals of epidote and plagioclase. The main mass of the rock consists of a fine mosaic of quartz, with dusty orthoclase and some plagioclase, and much irregularly shaped, partly sieve-like epidote. A little zircon is also present.

The limestones at Carmichael's, near Tamworth, furnish several interesting specimens. Rocks, like N.T., 444, consist of brownish garnet in a grey, silicate matter, set in a matrix of crystalline calcite. The silicate matter is made up of very finely divided orthoclase and oligoclase, quartz, wollastonite, and diopside. The garnets are pale brown, and are filled, sieve-like, with inclusions of the above minerals. In addition, there are small, square patches of more coarsely crystallised wollastonite, frequently associated with a little garnet and calcite. There are also grey-green, silicate rocks, containing coral-fossils (Syringopora?), the tubes of which have been filled with wollastonite, which, weathering more quickly than the main mass, exposes the markings on the coral tube-walls, in naturally etched specimens. The matrix differs from the last rock in containing green omphacite.

The rocks that occur on Horsearm Creek, near Attunga, are most handsome. They are chiefly composed of a cinnamon-brown garnet, frequently forming idiomorphic crystals. They are charged with chalcopyrite, which decomposes to azurite, colouring the rock very brilliantly. Certain parts of the rock become dark or black by the development of much magnetite with the chalcopyrite. One of the rocks [M.B., 128] consists chiefly of brown or reddish garnet, very irregular in outline, and full of inclusions of calcite, hornblende passing to chlorite, small plates of brown mica, chlori- 


\section{GREAT SERPENTINE BELT OF NEW SOUTH WALES, iii.,}

tising omphacite, and irregular reddish-brown areas, recalling the pleochroic decomposition-products of olivine in certain gabbros and basalts, though not quite like iddingsite. Magnetite, which is very abundant, and chalcopyrite, occur in irregular grains, the former having been the earlier to erystallise. The carbonate-matrix contains the same ferromagnesian minerals, and small grains of sphene. Another example contains calcite, garnet, and diopside only; while several are analogous to N.T., 444, at Carmichael's Farm. They consist of orthoclase and albite in intimate mosaic, together with finely granular quartz. Orthoclase predominates. Green diopside occurs, scattered about in irregular, isolated but optically continuous areas. Garnet forms highly irregular plates, and is sieve-like on the margin; it may contain groups of narrow calcite-plates.

Some rocks also occur, differing from the above in the presence of granular, green omphacite, and the dominance of oligoclase over orthoclase.

These rocks are distinguished from all the other limestones by the character of the garnets, and the presence of the copperminerals.

The small patch of altered limestones in Portion 159, of Attunga Parish, is the most complex. All the specimens to be described, occurred within a yard or two of each other, and no granite was seen, in situ, nearer than two miles away. It is probable that this small occurrence of metamorphic limestone lies at the extremity of an apophysis of the granite-massif, and has been in a favourable situation to receive much new material from the granitic emanations.

The intrusive rock is probably M.B., 167, a grey rock, with pink felspar-crystals. It consists of oligoclase and orthoclase, both coarsely granular, and the former showing well marked pericline twinning. There are also numerous, large grains of sphene. Much of the limestone has been absorbed, and has given rise to diopside in numerous prisms, and phlogopite in small flakes. Both of these are decomposing to chlorite. Birefringent garnets also occur. Much carbonate still remains, in one slice forming about one-third 
of the rock. The action of pneumatolysis is shown in the passage of the plagioclase into scapolite, which is commencing to form in isolated, but optically parallel plates throughout the felspar.

The limestone, before its alteration, was almost pure, and, in all probability, it had a composition little different from those cited above.

The types of altered limestones are many and varied, but a few will be described here.

M.B., 164, is a glistening, white, crystalline rock, consisting chiefly of wollastonite, often twinned, diopside, a little dark green, pleochroic hornblende, and some calcite. Orthoclase occurs interstitially, but is very decomposed. There are a few birefringent, reddish-brown garnet-grains, and some irregular grains of a highly birefringent, optically positive, uniaxial, pleochroie mineral, that is probably cassiterite, its refractive index being less than that of rutile.

There are also white crystalline rocks studded with idiomorphic and granular vesuvianite. Microscopically examined, the vesuvianite generally shows a sieve-like structure, containing numerous inclusions of phlogopite and calcite. It is set in a gronnd-mass composed of calcite, orthoclase, and prehnite, the last showing undulose extinction. The vesuvianite is zoned, and where it exhibits crystal-outline, there are peculiar, comb-like extensions from the crystal-surface into the matrix. The orthoclase is curiously stippled, and the carbonate is scattered through the rock in sharply bounded plates, elongated along (0001), and frequently well terminated. It also forms rhombohedra, and irregular grains. A small amount of irregular, brown garnet also is present. There are, in addition, a few small rods, and shorter prisms of colourless diopside.

Another type of rock, here, is the prehnite-garnet rock, which consists entirely of these two minerals, together with a few, irregular carbonate-grains or crystals, and a little, brown phlogopite. The garnets are in rounded grains and dodecahedral crystals, red-brown in the centre but paler on the periphery. They lie in a matrix of prehnite, with undulose extinction, and rarely showing spherulitic 
arrangement(Plate xxix., Fig. 16). The garnets are often surrounded by one or two thin shells of garnet, separated from the main crystals by prehnite, sometimes optically continuous with that of the ground-mass. Finally may be noticed, a pink crystalline rock, studded with deep red garnets [M.B., 165]. This is a most complex rock. It consists of beautifully zoned, red garnets, a small amount of vesuvianite, with very anomalous, unusually high, birefringence, and positive optical character (a rare feature); a considerable amount of orthoclase, and also albite, some calcite, and a brightly polarising ground-mass, part of which is wollastonite, but which has undergone some alteration, and recrystallisation that cannot be traced throughout in the single specimen available.

If the determination of cassiterite in 164 be correct, it is evident that these rocks must have been affected by highly active, pneumatolytic solutions.

(3) The Baldwin Agglomerates present an exaggeration of the features of the Tamworth breccias. In the northern part of Hall's Creek, near Bingara, where they become finer-grained, it is impossible to distinguish them from the breccias, but, further south, the size of the inclusions and their general characters become very distinct. They were partially described by Messrs. David and Pittman(3), who state that the matrix of the Cleary's Hill rock has the appearance of the interstratified tuffs. It consists of much fractured and corroded, macroscopic crystals of felspar and augite, and calcite, with interstitial felsitic material, and here and there small fragments of microcrystalline felsite, and larger, pebble-like lumps of porphyritic andesite. The felspar is plagioclase, and, in addition, quartz, ilmenite, pyrites, and epidote occur. In other instances, much chlorite and prehnite are found. In this matrix, a wide variety of pebbles is found. The following may be noticed: granite and quartz-porphyry (rarely); keratophyres with phenocrystic albite and orthoclase(?), in a felsitic, sometimes spherulitic, base; black keratophyre with albite-orthoclase and augitecrystals in a glassy, fluidal base, enclosing fragments of other glassy keratophyres, rich in magnetite; trachytes; spilites, very similar to those in the Eastern Series; trachy-andesites, with car- 
bonate replacements of their ferromagnesian minerals, andesites, porphyritic, holocrystalline, or more or less glassy, vesicular or even pumiceous, with the cavities filled with calcite and chlorite; basalts, vesicular or glassy, differing from the andesite only in the amount of magnetite; augite-diorite porphyries, as described by David and Pittman, with phenocrysts of plagioclase, orthoclase, augite, and sphene in a greyish felsitic ground-mass(in hand-specimen, this rock resembles the malchites of the Nundle district, but the microscope shows it to be distinct, and allied to the Tamworth tuffs); dolerite containing granophyric quartz, and very similar to the rock of Hanging Rock, near Nundle; chert, in large or small angular fragments, often radiolarian; limestone, either in dense blue rocks or more crystalline, sometimes containing fossils, as Heliolites, Syringopora, Stromatopora and crinoidstems, or indeterminable traces of microscopic forms; and numerous, isolated crystals or fragments of felspar, quartz, and augite.

These rocks rest directly on radiolarian rocks at Tamworth; they rest on, or are interbedded with the same cherts west of Bingara; they contain interstratified bands of chert with radiolaria, or, as in Cobbadah Creek Gorge, fine-grained tuffs, composed of minute felspar-laths with pyroxene, and secondary chlorite and prehnite in a very finely granular ground-mass of quartz and felspathic material, which also contains some radiolarian casts. In three localities, flows of porphyritic spilite-lava have been found, inter bedded in these agglomerates.

(4) The Barraba Series consists of mudstones, tuffs, breccias, and limestones. The mudstones and claystones do not differ in microscopical character from those of the Tamworth Series, to any great amount. The chief changes are in the coarse grain of the majority of the series, and in the abundance of narrow bands of felspathic tuff. The rocks are well bedded, and consist of fragments of quartz and felspar, with a little chlorite and an irresolvable base, the whole stained more or less with iron-oxide. Carbonaceous matter may, or may not, be present. In certain rocks, it is very abundant. The tuff is interlaminated, usually in very thin bands, perhaps 
only $1 \mathrm{~mm}$., across, but sometimes increasing up to a yard or more in width. The rocks are sometimes richly radiolarian, and at other times quite free from these organisms. The only apparent distinetion is in the size of the constituent particles, for the radiolaria do not usually occur in rocks in which the grains of sediment, quartz, ete., are more than about one-third of the diameter of a radiolarian test, and are best preserved in rocks of the finest grainsize. This rule does not hold, however, for the tuffaceous bands, and abundant radiolaria may be present in association with quite large felspar-grains, as will be seen in Plate xxix., Fig. 18, from a rock [M.B., 71], occurring one mile east of Barraba. Nor is it true that the radiolaria are most abundant in the fine-grained rocks; the well preserved radiolaria of the exceedingly fine-grained rock [M.B., - ], occurring near the limestone on Hall's Creek, 15 miles south of Bingara, are not nearly so abundant as in the more coarsely-grained rocks of Barraba and Upper Manilla, or as in the rock, N.T., 410, from near Nundle, shown in Plate xxix., Fig. 17, which exhibits the effect of crushing. This rock is very rich in earbonaceous matter.

The breccias and agglomerates occur in narrow bands here and there, but need no special description, being very similar to the Baldwin agglomerates, but are not so coarsely grained. Locally also, the presence of pebbly and sandy bands has been noted among the Barraba rocks.

The tuffs are remarkable for the sharply bounded character of their grains and in their acidity, for they are albite-oligoclases with a refractive index distinctly lower than that of Canada balsam. In some rocks, however, the plagioclase is a more basic oligoclase. In some specimens, a few grains of orthoclase occur. The felspathic tuff is usually a creamy-coloured rock, and sometimes it may contain plant-stems. Occasionally, there are very fresh, hard layers which, in hand-specimen, are most difficult to tell from true igneous felsite, and the intrusions would be mapped as sills, were it not for the absence of contact-effects. Such occurrences are found on Hawkin's Creek, near the Horton Road, west of Barraba, in the hills east of Upper Manilla, and, again, on the 
other side of the area of older rock to the east. These are almost identical, microscopically [see M.B., 76, and 263], and their clastic nature is quite obvious. They are chiefly acid plagioclase in crystals and grains, with a little quartz, and a finely felsitic groundmass. Considering the geological occurrence of the rock, there is a surprising amount of crushing and bending of the felspar. Magnetite, chlorite, epidote, and calcite occur in varying amounts; apatite very rarely. The impression given by the felspar-grains, that they have been derived from a granodiorite or diorite, is strengthened by the investigation of M.B., 63, a tuff on Cobbadah Creek, about one mile west of the serpentine, of which, however, the stratigraphical horizon is not known. It is practically a disintegrated diorite, consisting of hornblende, quartz, and minor amounts of colourless augite; biotite, orthoclase, magnetite, apatite, zireon, and pyrites, together with small fragments of cherty mudstone, and andesite. There is a small amount of fine-grained matrix composed of the same minerals, comminuted and decomposed. A rather similar rock occurs on Borah Creek, west of the Black Mountain fault.

The limestones of this series are a fairly constant feature, dark blue in colour, with a white or greyish weathering surface, They are exceedingly finely grained, and never show any sign of original, organic structure. Occasionally, there are a few lighter rhomboid or rectangular patches, which stand out on weathered surfaces, and are probably pseudomorphs, but the original mineral is quite indeterminable. There is more or less carbonaceous matter present, and sometimes finely divided quartz.

(5) The Burindi Series consists of mudstones, tuffs, agglomerates, and limestones, with occasional conglomerate-bands. The mudstones are indistinguishable from the coarser type of the Barraba Series, until the fossil-bearing horizons are reached, where the rock becomes finer-grained, and darker green in colour, probably due to increase in the amount of chlorite and carbonaceous matter. The tuffs and agglomerates, also, are identical with those of the Barraba Series. A rock, the stratigraphical position of which is quite uncertain, though mapped as of Burindi age, is that 
occurring adjacent to the serpentine, west of Gulf Creek. It should possibly be classed with the Rocky Creek beds, for it consists of a mass of rhyolite and trachyte-fragments of several types, with quartz-grains in a finely divided quartz and felspar ground-mass [N.T., 483].

The limestones are of several types. Where fossiferous, they are remarkable for being composed almost entirely of crinoidossicles, and are sometimes quite pure, at other times very ferruginous. Oolitic limestones occur at several localities. That near the junction of the Horton River with Rocky Creek, was briefly described by Mr. Etheridge(see Stonier's Map, 6d). Oolitic limestones occur also near Mr. Hamilton's house on Oakey Creek, five miles south of Warialda. That near the serpentine, half a mile east of the house, consists of normal, zoned, radially fibrous oolites, about $3 \mathrm{~mm}$., in diameter, in a tuffaceous matrix of quartz-grains, felspars, chlorite, and fragments of a basaltic rock. Crinoidossicles are also present abundantly.

Some limestones of this series, as, for instance, a small band by the Hall's Creek Falls [M.B., 284] are very impure, full of pebbles, weathering with a brown crust, and are indistinguishable from the Devonian limestone occurring near Cuerindi [M.B., 85, p. 711]. Nothing especially noteworthy, petrologically, is to be remarked in the very fossilferous Lithostrotion limestone near here. It is fairly pure and crystalline.

(6) The Rocky Creek Series consists of volcanic flows, tuffs, conglomerates, grits, sandstones, and cherty rocks. The clastic rocks all contain fragments of the interbedded lavas, and of other igneous rocks also. Even the finest-grained cherty rocks contain fragments of granite. There are not, however, as far as has been noted, any red jaspers or other rocks comparable with the rocks of the Eastern series, to be found as inclusions in the Rocky Creek beds. The suspicion that arose, in one or two cases, has been dispelled on microscopical examination. The following are micropetrological notes on a few slides:-

Cherts: [M.B., 16]. Interbedded in the conglomerates on Rocky Creek. Composed of very finely grained, angular quartz and fel- 
spar-fragments, with a very little kaolin, chlorite, and magnetite. Fragments of trachyte and granite, and, occasionally, large, broken erystal-grains.

Jasper: [M.B., 120]. Pebble in conglomerate; composed of very fine, even-grained quartz, and abundant biotite; no signs of radiolaria are visible.

Pebbles of igneous rocks: all the rhyolites described in the earlier portion of this chapter ( $p . \quad$ ). Many varieties of trachyte and rhyolite-tuff in various stages of decomposition. Several kinds of granitic rock, e.g., M.B., 8, a rock composed of phenocrysts of felspar and quartz, in a coarse-grained, granophyric matrix, with a little magnetite, sphene, and chlorite after biotite. Also, M.B., 347 , a granodiorite with included fragments of a finer-grained rock (microdiorite), differing from its host only in grain-size, the rarity of quartz, and the abundance of the ferromagnesian minerals. It consists of hornblende, magnetite, sphene, and oligoclase, with a little orthoclase.

Aplites and quartz or felspar porphyries are abundant. Rocks of a basic character, however, are notably absent.

I am indebted to Mr. A. B. Walkom, B.Se., for sections of many of these rocks, and for comparison of the rhyolites with those he has studied from Pokolbin, 200 miles to the south.

(7) The Permo-Carboniferous rocks are sandstone, in Bowling Point and in the Nandewar region. The former consists of abundant, rounded or subangular, fairly fresh grains of plagioclase, with smaller, angular grains of quartz; fragments of keratophyre (?) and spilite in a fine-grained, felspathic matrix, coloured with chlorite, limonite, ete. There are no signs of straining or crushing(Slide, N.T., 204).

Rocks of Uncertain Origin.-A most remarkable rock occurs, forming a large, oval patch in the serpentine, at the head of Yellow Rock Creek, south of Crow Mountain. It consists of a white, granular matrix, containing long, green, prismatic(?) crystals. Microscopically [M.B., 231, and 262], it is seen to consist chiefly of zoisite and clinozoisite. The former is the more abundant. It has a well marked, prismatic habit and cleavage, and characteristic, 
low, anomalous birefringence, and is in grains $1 \mathrm{~mm}$., or more, in diameter. The clinozoisite has a less well-marked cleavage, and its polarisation-tints pass zonally from low outer colours, to bright second order tints, in the kernel of the grain. In addition, there are large flakes of white mica, and, interstitially, large plates of felspar, chiefly oligoclase and possibly some orthoclase. Large grains of apatite are present in some amount, and there are a few grains of sphene; a very little calcite is also present. The greenish mineral, though in hand-specimen it suggests hornblende, is microscopically without definite structure, consisting of aggregated chlorite-spherulites.

The origin of this rock is unknown; the only suggestion, at all reasonable, seems to be, that it is a highly altered gabbro-pegmatite; but that is quite unproven.

The statement, that glaucophane-schist occurs near Barraba, has appeared in print. The specimen at first attributed to the Barraba district, later was stated to some from Gilgai, near Inverell; and the specimen was carefully described by Mr. H. P. White(48) as from that locality. Mr. L. A. Cotton informs me, that he knows of no locality, near Gilgai, where it might have occurred; and no signs of such rocks were found near Barraba by me, though, mindful of Ransome's discoveries in Angel Island(49), I carefully searched the whole length of the serpentine-belt for glaucophanerock. Possibly it was brought by a miner from New Caledonia, at the northern end of which, such rocks are abundant.

\section{BIBLIOGRAPHY;}

Additional to References cited in Parts i. and ii.

34. Geol. Survey of Great Britain. "The Geology of the Launceston and Tavistock District Sheet." Memoir 337, p.63.

35. Pratt, J. H., and Lewis, J. V.—“Corundum and Peridotites." Bull. Geol. Surv. North Carolina, No.1, p.30.

36. Bonney, T. G., and Raisin, C. A.- "'The Microscopical Structure of the Minerals forming Serpentine, and their Relation to its History." Quart. Journ. Geol. Soc., 1905, pp.690-715. 
37. Lacroix, A.—“La Minéralogie de France et ses Colonies."

38. Benson, W. N._-"The Volcanic Necks of Hornsby and Dundas." Journ. Proc. Roy. Soc. N. S. Wales, 1910, p.509.

39. Dixon, W. A.-Ann. Rept. Dept. Mines N. S. Wales, 1879.

40. Flett, J. S., and Hill, J. B.- "The Geology of the I.izard and Meneage." Memoirs Geol. Surv. Great Britain, 1912.

41. Murgoci, G.-Ueber die Einschlusse von Granatvesuvianfels in dem Serpentin des Paringû Massifs." Bulletinul de Sciinte, Bukarest. ix. Jahrgang, 1900.

42. JudD, J. W._- On some simple Massive Minerals (Crystalline Rocks) from India and Australia." Mineralogical Magazine, 1895, p.63.

43. Bell, J. M., Marshall, P., and Clarke, E. DeC. - "The Geology of the Dun Mountain Subdivision." Bull. Geol. Surv. of New Zealand, No.12, 1911, pp.31-35.

44. Marshall, P.- "Note on the Gabbro of Dun Mountain." Trans. N.Z. Inst. — - pp.320-322. Also, "The Geology of the Dun Mountain Subdivision." Bull. Geol. Survey of New Zealand, No.12, 1911, pp.31-35.

46. CARD, G. W, - "An Eclogite-bearing Breccia from the Bingara Diamond Fields." Rec. Geol. Surv. N. S. Wales, Vol. vii., p. 39.

46. Jevons, Jensen, Sussmilch, and Taylor. - "Geology and Petrology of the Prospect Intrusion." Journ: Proc. Roy. Soc. N. S. Wales, 1911, pp.445-553.

47. Carne, J. E. - "The Copper Mining Industry." Geol. Surv. N. S. Wales. Mineral Resources, No. 6, pp.322-6.

48. White, H. P.- "Chemical Notes on Glaucophane Schists from Australia and New Caledonia." Rec. Geol. Surv. N. S. Wales, Vol. vii., p.47.

49. Ransome, F. L.-“The Geology of Angel Island.” Bull. Dept. Geol., Univ. of California, Vol. i., No.7, pp.198.224(1894).

\section{EXPLANATION OF PLATES XXVII.-XXIX.}

\section{Plate xxvii. Photomicrographs.}

Fig. 1. - Spilite [N.T., 415]; Frenchman's Spur, Nundle $(\times 20)$.

Fig.2.-Spilite, rapidly chilled [N.T., 31]; Moonlight Hill, Nundle ( $\times 100)$. Fig. 3. - Dolerite with primary labradorite, and abundant ilmenite [N.T., 501]; Red Rock, Munro's Creek, Bowling Alley Point $(\times 12)$.

Fig.4.-Albitised dolerite, with spongy felspar [N.T., 327]; Hanging Rock, Nundle $(\times 22)$ [polarised light].

Fig.5.-Flow-structure in lava [M.B.,233]; Jerry's Creek, Crow Mountain. Fig.6. - Spherulitic rhyolite, with flow-structure [M.B., 1]; pebble in conglomerates, Rocky Creek $(\times 20)$ [polarised light]. 


\section{Plate xxviii. Photomicrographs.}

Fig. 7.-Bastite in schistose serpentine, with chrysotile-veins; "North of Tamworth" $(\times 12)$ [polarised light].

Fig. 8. - Antigorite ccmmencing to form in normal mesh-serpentine [N.T., 258]; Bowling Alley Point $(\times 22)$ [polarised light].

Fig.9.-Antigorite completely replacing normal serpentine, and commencing to form in bastite [N.T., 383]; Bowling Alley Point $(\times 10)$ [polarised light].

Fig. 10.-Tremolite-antigorite-chromite rocks [M. B., 319]; Hall's Creek, 15 miles south of Bingara $(\times 12)$ [polarised light].

Fig.11.-Multiply twinned clinozoisite in saussurite-gabbros [M.B., 181]; 3 miles W.S. W. of Gulf Creek $(\times 10)$ [polarised light].

Fig.12.-Amphibolite passing into antigorite, showing multiple twinning of the hornblende [M.B., 186]; Paling Yard, Barraba $(\times 20)$ [polarised light].

\section{Plate xxix. Photomicrographs.}

Fig. 13.-Intrusion of plagioclase-porphyry (left) into spilite (right) [N.T., 89]; Bowling Alley Point $(\times 12)$.

Fig.14. - Vosgesite [M.B., 144]: 6 miles north of Attunga $(\times 22)$.

Fig.15.-Camptonite [M.B., 228]; near Crow Mountain ( $\times 21)$.

Fig.16.-Prehnite and garnet in contact-altered limestone [M.B., 163]; Attunga ( $\times 11)$ [polarised light].

Fig.17.-Radiolarian mudstone [N.T., 410]; Nundle ( $\times 20$ ).

Fig. 18.-Radiolarian mudstone with felspathic (tuffaceous ?) bands [M.B., 71]; Barraba $(\times 22)$.

\section{CORRIGENDA.}

P.662, line 5-for Plates xxv.-xxvii., read Plates xxvii.-xxix.

Pp.664, 666, 667, 669, in the references to figs.1-6-for Pl. xxv., read Pl. xxvii.

Pp.673, 674, 675, 681, 689, in the references to figs.7-Il-for Pl. xxvi., read Pl. xxviii.

Pp.694, 697, 699, in the references to figs.13-15-for $\mathrm{Pl}$ - xxvii., read $\mathrm{Pl}$. xxix. 


\section{$2 \mathrm{BHL}$ Biodiversity Heritage Library}

Benson, W. N. 1914. "The geology and petrology of the Great Serpentine Belt of New South Wales. Part iii. Petrology." Proceedings of the Linnean Society of New South Wales 38, 662-724. https://doi.org/10.5962/bhl.part.13573.

View This Item Online: https://www.biodiversitylibrary.org/item/30155

DOI: https://doi.org/10.5962/bhl.part.13573

Permalink: https://www.biodiversitylibrary.org/partpdf/13573

\section{Holding Institution}

MBLWHOI Library

\section{Sponsored by}

MBLWHOI Library

\section{Copyright \& Reuse}

Copyright Status: NOT_IN_COPYRIGHT

This document was created from content at the Biodiversity Heritage Library, the world's largest open access digital library for biodiversity literature and archives. Visit BHL at https://www.biodiversitylibrary.org. 